\title{
Mandatory audit fee disclosure and price competition in the private client segment of
}

\author{
the Belgian audit market
}

\begin{abstract}
This study empirically examines whether mandatory audit fee disclosure affects audit pricing and price competition in the private client segment of the Belgian audit market. We expect price competition between auditors to intensify after mandatory public disclosure of audit fees because transparency of audit fee information is likely to increase client bargaining power and/or increase competitive pressure. Using a data set including both pre- and post-disclosure audit fees of private clients, we observe that subsequent to mandatory disclosure of audit fees, clients with positive (negative) abnormal audit fees experience a downward (upward) fee adjustment. Consistent with increased price competition following mandatory audit fee disclosure, clients with negative abnormal audit fees are better able to mitigate the upward fee adjustment if they have higher bargaining power or have an auditor facing stronger competitive pressure. These effects are largest in the initial disclosure year, suggesting anticipatory price adjusting behavior by audit firms.
\end{abstract}

Keywords: Audit fees, mandatory disclosure, client bargaining power, competitive pressure, private client segment

\section{Introduction}

The objective of this paper is to empirically examine whether mandatory public disclosure of audit fees affects audit pricing and price competition in the private client segment of the Belgian audit market. First, we explore whether mandatory audit fee disclosure affects subsequent audit pricing. Second and more importantly, we aim to gain insights into the effect of mandatory audit fee disclosure on the relationships between clients and their auditor, as well as between auditors and their competitors. Specifically, we explore whether and how client bargaining power and competitive pressure between auditors influence the effect of mandatory audit fee disclosure on subsequent audit fees.

In some countries, such as the United Kingdom (Companies Act, 1967) and Australia (Uniform Companies Act of 1961-1962), mandatory disclosure of audit fees already exists for several decades, whereas it has only been established in the last two decades in many other countries, such as the United States (US) (US Securities and Exchange Commission (SEC)), 2000), and the European Union (EU) (for example, Germany (BilReG, 2004) and Belgium 
(Royal Decree, 2007)). In the aftermath of various accounting scandals (e.g., Enron, Lernout \& Hauspie, WorldCom), the introduction of audit fee disclosure regulation was mainly triggered by concerns about auditor independence arising from incumbent auditors providing both audit and non-audit services. While mandatory fee disclosure provides information with regard to fees paid to the auditor and the scope of services provided by auditors to their clients, it is also likely to increase competitive pricing in the audit market. Anecdotal evidence suggests that auditors did not encourage the mandatory disclosure of the actual values of audit and non-audit fees, but rather favored mandatory disclosure of the ratio of audit over non-audit fees (or the ratio of non-audit over audit fees). ${ }^{1}$ Specifically, the concern was that mandatory disclosure of (non-)audit fees would lead to higher pressure on audit fees in addition to the provision of information about the client-auditor relationship ${ }^{2}$. In this study, we consider the effect of mandatory audit fee disclosure on price competition in the audit market. Hence, results from our study may help elucidate the role of publicly available information in the pricing of audit services and competitiveness of the audit market and are, therefore, of interest to scholars, regulators, and policy makers.

Francis and Wang (2005) are the first addressing the impact of mandatory audit fee disclosure on subsequent audit pricing. Their evidence suggests that public audit fee disclosure in the US improved the precision of audit pricing (less variance in audit fees) and that audit fees have been adjusted downward to a greater extent for "overcharged" clients than adjusted upward for "undercharged" clients. More recently, Su and Wu (2017) obtain similar results in the Chinese audit market. We add to these studies in two important ways.

\footnotetext{
${ }^{1}$ Dirk Van Vlaenderen, former audit partner of Deloitte, personal communication, December 19, 2013 and February 22, 2018; Kurt Cappoen, audit partner of PwC, personal communication, February 23, 2018; Gert Maris, audit partner of BDO, personal communication, March 2, 2018.

${ }^{2}$ This concern was also raised during the European study day - The quality of external audit, a lever for the European economy (February 10, 2012), jointly organized by the Instituut van de Bedrijfsreviseren (Belgium), the Compagnie Nationale des Commissaires aux Comptes (France), and the Nederlandse Beroepsorganisatie van Accountants (the Netherlands).
} 
Firstly, Francis and Wang (2005) and Su and Wu (2017) conclude that public disclosure of audit fees gave clients increased bargaining power over auditors based on the observation that in the period subsequent to the disclosure regulation, audit fees were adjusted downward to a greater extent for clients with positive abnormal audit fees than adjusted upward for clients with negative abnormal audit fees. However, Francis and Wang (2005) and Su and Wu (2017) do not explicitly test the impact of client and auditor bargaining power in their analysis. We extend their analysis by including measures for client bargaining power and competitive pressure on auditor bargaining power to assess how these factors affect adjustments in audit pricing following the mandatory public disclosure of audit fees.

Secondly, Francis and Wang (2005) and Su and Wu (2017) focus on public client information and consequently, the impact of mandatory audit fee disclosure regulation on audit pricing and price competition is yet unexplored in the private client segment of the audit market. We believe that examining this issue in the private segment of the audit market is relevant for several reasons. As argued by Langli and Svanström (2014), research focusing on public clients may not be generalizable across the entire audit market since the audit setting of the private client segment differs from the public client segment. The private client segment of the audit market does not only include clients in need of a high-quality auditor (i.e., quality-seeking clients) but also clients looking for the cheapest auditor only to fulfill legal audit requirements (i.e., price-seeking clients) (Willekens \& Achmadi, 2003; Chaney, Jeter, \& Shivakumar, 2004). Therefore, prior studies often assume that price competition, rather than quality competition, prevails in the private client segment of the audit market because of its low concentration (see e.g., Simunic, 1980). As a result, audit fee adjustments resulting from mandatory audit fee disclosure might differ for private clients relative to public clients. While a downward fee adjustment (which is in favor of the private client) might be easy to accept, an upward fee 
adjustment might be more difficult to negotiate in this more price competitive segment of the audit market.

In addition, private firms are of economic importance as they represent the majority of the EU economy and the EU market for audit services. Small and medium-sized companies represent more than 99 percent of European companies and are also considered to be the backbone of European economy (Federation of European Accountants, 2016; Vanstraelen \& Schelleman, 2017). In Belgium, the private client segment of the audit market is predominant. Studying audit pricing in the Belgian audit market, Van Caneghem (2010) reports that 99 percent of his sample are private firms and this accounts for about 94 percent of the total audit fees charged by Belgian auditors. As argued by Vanstraelen and Schelleman (2017), research on the external audit of private firms is much more limited than that of public firms and, thus, additional studies using private client information are needed to extend the auditing literature. For these reasons, the private client segment of the (Belgian) audit market provides a relevant setting to explore the issue under study.

We use a data set that includes both pre- and post-disclosure audit fee data, which enables us to investigate the impact of mandatory audit fee disclosure regulation on audit pricing and price competition in both the period surrounding as well as the period after the implementation of the requirement. Based on a balanced sample of 18,939 firm-year observations (relating to 6,313 unique clients) from both before (the year 2004) and after (the year 2010) mandatory disclosure, our analyses indicate an overall increase in audit fees over this seven-year time span.

However, from the point that disclosure becomes mandatory (i.e., 2007 and onwards), clients with a positive abnormal audit fee ${ }^{3}$ are able to negotiate a downward fee adjustment, irrespective of their bargaining power (i.e., importance in the auditor's portfolio) or competitive pressure that the auditor faces from its closest competitors. Clients with a negative abnormal

\footnotetext{
${ }^{3}$ We define abnormal audit fees as the unexplained variance in audit fees after controlling for client/auditor/engagement characteristics, so positive (negative) residuals capture clients with a positive (negative) abnormal audit fee.
} 
audit fee face an upward fee adjustment during the same time period, but they are better able to mitigate the upward fee adjustment if they have higher client bargaining power or if their auditor faces higher competitive pressure. These effects are largest in the initial disclosure year, which suggests anticipatory price adjusting behavior by auditors. That is, because mandatory public disclosure of audit fees was announced before the actual requirement came into effect (cf. 4.1 Audit fee disclosure regulation), audit firms may have anticipated the potential public disclosure of audit fees in their pricing. In sum, while mandatory fee disclosure was enforced to provide insight into the client-auditor relationship and to enhance auditor independence, this study provides evidence of another consequence, that enhanced competitive pricing in the private client segment of the audit market.

The remainder of the paper is organized as follows. In Section 2, we present previous literature on mandatory audit fee disclosure. In Section 3, we develop our hypotheses with regard to client and auditor bargaining power. In Section 4, we discuss the institutional setting. We discuss our research design in Section 5 and Section 6 presents our results, including additional and sensitivity analyses. Finally, in Section7, we discuss the conclusions and limitations of this study.

\section{Literature review}

Audit services are a credence good because the quality of the service provided is not directly observable by the client or other participants in the market (Causholli \& Knechel, 2012). Before mandatory disclosure of audit fees, both quality and prices of audit services were unobservable. Clients only received price information during the tendering process when attracting and appointing an auditor. In contrast, auditors had private information about fees charged to their own clients (Mayhew, 2005). This incomplete price information created information asymmetry among audit market participants and provided auditors a source of 
market power and an incentive to act strategically (i.e., under-audit, over-audit, or overcharge) to their own advantage (Causholli \& Knechel, 2012).

After mandatory audit fee disclosure is imposed, clients as well as auditors are able to freely compare audit fees charged by auditor-competitors to (other) clients in the market with those charged for similar engagements. Reducing incomplete information through disclosure can lower prices because it improves comparative and freely available price information among market participants (Carlton \& Perloff, 2005; Belleflamme \& Peitz, 2010). Publicly available audit fee information reduces a client's search effort to learn more about the potential cost of services offered by alternative service providers. Lower search costs reduce market frictions, which in turn results in more competitive markets and should lead to lower prices, ceteris paribus (Francis \& Wang, 2005). As demonstrated by Verrecchia (2001), disclosure reduces information asymmetry among market participants and enhances pricing precision. Indeed, subsequent to mandatory disclosure of audit fees required by the US SEC, Francis and Wang (2005) observe a reduction in audit fee dispersion.

Both auditors and clients can use the publicly available price information to their own advantage, and both parties are likely to gain bargaining power in the audit market. A client with a positive abnormal audit fee prior to disclosure will gain bargaining power over the auditor in negotiating a more favorable fee if the client effectively uses the publicly available audit fee information (Mayhew, 2005). That is, the client will not be willing to pay an auditor more than a competitor charges in the same market, unless the client is seeking service from a high(er)-quality auditor that is more expensive. As such, a client which is paying more than what is average in the audit market (or, a client with a positive abnormal audit fee) could threaten to replace its auditor if the auditor is not willing to reduce the fee that is charged.

In a similar vein, it is reasonable to expect that clients with a negative abnormal audit fee prior to disclosure will face an upward fee adjustment in the period subsequent to mandatory 
disclosure because both parties (i.e., auditor and client) can observe the extent to which the client is undercharged relative to similar clients in the market. The incumbent auditor might be able to negotiate an upward fee adjustment based on the following considerations: (i) the auditor gains bargaining power over its client if a lower fee alternative does not appear to exist (i.e., the auditor charges an audit fee that falls below that of its competitors); (ii) a negative abnormal audit fee is likely to signal low(er) audit quality to other market participants, which might convince the client to increase the audit fee; and/or (iii) the auditor can convince the client that the audit service provided differs in terms of quality from services provided by other auditors in the market (Dye, 1991; Francis \& Wang, 2005; Mayhew, 2005).

In line with the aforementioned arguments, Francis and Wang (2005) find that clients with a positive (negative) abnormal audit fee in the initial audit fee disclosure year have a significantly lower (higher) fee in the year subsequent to disclosure. This suggests that mandatory audit fee disclosure enhanced competitive pricing in the audit market. However, Francis and Wang (2005) only use post-disclosure audit fee data of public clients and assume that audit fees are unaffected in the initial public disclosure year. Using pre- and post-disclosure audit fee data of public clients, Su and Wu (2017) find audit fee adjustments to occur in both periods. However, the magnitudes of downward (upward) audit fee adjustments are significantly higher (lower) in the post-disclosure period relative to the pre-disclosure period, which implies that public audit fee disclosure affects subsequent audit pricing.

\section{Hypotheses Development}

Francis and Wang (2005) and Su and Wu (2017) observe that fees are adjusted downward for clients with positive abnormal audit fees to a greater extent than adjusted upward for clients with negative abnormal audit fees in the period subsequent to the audit fee disclosure regulation. Therefore, they conclude that public disclosure of audit fees gave clients increased bargaining 
power over auditors. While both Francis and Wang (2005) and Su and Wu (2017) implicitly test how public disclosure of audit fees affected both parties' bargaining power, we extend their analyses by explicitly considering the impact of both client bargaining power and competitive pressure on auditor bargaining power for audit fee adjustments subsequent to disclosure. That is, while incomplete information is reduced for all clients and auditors, the extent to which they can actually exploit the publicly available information is likely to depend upon their bargaining power. In what follows, we propose hypotheses regarding the impact of client bargaining power and competitive pressure on audit fee pricing in the period following the disclosure regulation.

\subsection{Client bargaining power}

We expect that, from disclosure onwards, a client with a positive abnormal audit fee will be able to negotiate a downward fee adjustment (Francis \& Wang, 2005; Su \& Wu, 2017). However, the downward fee adjustment and its magnitude depend on whether the auditor fears losing the client. That is, not all clients are equally important in the auditor's portfolio. Clients with positive abnormal audit fees and relatively greater importance (in terms of relative size) in the auditor's portfolio are more likely to be able to negotiate a larger reduction in their audit fee than clients that are less important. Casterella, Francis, Lewis, and Walker (2004) show that clients with higher bargaining power (i.e., in terms of relative size in the auditor's industry portfolio) pay lower audit fees. A similar reasoning applies to clients with a negative abnormal audit fee prior to disclosure. Since both auditor and client can observe the extent to which the client is undercharged relative to similar clients in the market, it is reasonable to expect that clients with negative abnormal audit fees will face an upward fee adjustment in the period subsequent to the disclosure regulation. Nevertheless, clients with negative abnormal audit fees and greater relative importance in the auditor's portfolio might be able to negotiate a smaller increase in audit fees subsequent to disclosure than clients that are less important. In sum, we 
predict that client bargaining power will affect the adjustment of the audit fee in the client's favor subsequent to the mandatory public disclosure of audit fees. This prediction results in the following hypothesis:

Hypothesis 1: After mandatory audit fee disclosure, clients with a positive (negative) abnormal audit fee and higher bargaining power will be able to negotiate audit fees more downward (less upward) than clients with positive (negative) abnormal audit fees and lower bargaining power.

\subsection{Competitive pressure}

Auditors can obtain bargaining power over clients by providing quality-differentiated services in their market. Some clients are willing to pay for these services, which enables auditors to charge higher audit fees (i.e., a brand name or industry specialist premium; for a review see Hay, Knechel, and Wong (2006) and Hay (2012)). However, auditor bargaining power will not only be affected by the client-auditor relationship but also by auditorcompetitors. Before disclosure was mandatory, each incumbent auditor had power over other auditors in the market because only the incumbent auditor knew how much was charged to a specific client. From disclosure onwards, all auditors can freely access audit fees charged by other auditors in the same market. Therefore, information asymmetry among competitors is decreased, and all auditors are now able to strategically use the publicly available price information when competing for new clients or maintaining their existing clients.

In a related vein, Hay and Knechel (2010) reveal that reduced information asymmetry regarding the content and prices of audit services due to deregulation of advertising and solicitation influences strategic behavior of auditors and competition in the audit market. Numan and Willekens (2012a) examine how competition through industry differentiation (i.e., auditor bargaining power) affects audit pricing and find effects not only due to characteristics of the incumbent audit firm, but also the strategic behavior of competitors in the audit market. 
Audit fees are found to increase according to the industry market share distance from the closest competitor, suggesting more competition and lower audit fees if the closest competitor of the incumbent auditor is situated nearby in terms of industry market share distance. In summary, it is reasonable to expect that as publicly available information through mandatory disclosure increases, resultant strategic behavior of auditors will have a greater impact on the market for audit services and result in greater competition among auditors.

As stated above, depending on whether the client has a positive or negative abnormal audit fee, a downward or upward adjustment to the fee is expected subsequent to the mandatory disclosure regulation. Auditors with relatively higher auditor bargaining power might be able to mitigate the downward fee adjustment or heighten the upward fee adjustment to their own advantage. That is, clients with a positive (negative) abnormal audit fee might be willing to accept a smaller (larger) downward (upward) fee adjustment because they are willing to pay for quality-differentiated services provided by their incumbent auditor. However, because of the presence and strategic behavior of other auditors in the market, competitive pressure might reduce the bargaining power of the incumbent auditor. If an auditor faces fierce competition from (many) qualitatively comparable competitors in the same market (as in the private client segment of the audit market), that auditor's bargaining power might be under (competitive) pressure. That is, clients who are able to choose an auditor from a "wide range" of auditors providing the service at a similar quality level as their incumbent auditor might be more willing to switch auditors if they are not satisfied with the audit fee adjustment offered by their incumbent auditor following the disclosure regulation. In contrast, if auditors can clearly distinguish the quality of their services from the quality of the services offered by competitors in the market, their bargaining power might not be (or only be limitedly) pressured (i.e., if the client is looking for a quality-differentiated service). Consequently, we predict that from mandatory disclosure onwards higher competitive pressure will lower auditors' bargaining 
power, undermining their ability to mitigate downward fee adjustments or heighten upward fee adjustments to their own advantage, resulting in the following hypothesis:

Hypothesis 2: After mandatory audit fee disclosure, the downward (upward) fee adjustment of clients with positive (negative) abnormal audit fees will be smaller (larger) in more competitive segments of the audit market than in less competitive segments of the audit market.

\section{Institutional setting}

\subsection{Audit fee disclosure regulation}

In May 2006, the European Parliament and the Council announced a directive on statutory audits of annual accounts and consolidated accounts including the requirement of public disclosure of audit and non-audit fees in clients' financial statements (European Parliament and Council, 2006). The overall aim of the directive was to harmonize statutory audit requirements, applicable to all statutory audits of public as well as private clients, across all EU member states. Although most of the specifications in the directive were related to statutory audits of both public and private clients, the directive also focused on requirements specifically related to the performance of audits of public interest entities ${ }^{4}$. All EU members were obliged to incorporate the directive into their national legislation before mid-June 2008.

In April 2007, Belgium enacted the directive in a Royal Decree and public disclosure of both audit and non-audit fees became mandatory for all large Belgian firms ${ }^{5}$ starting with the accounting year ending on June 30, 2007. Belgium provides an interesting setting for two reasons: (i) all EU member states had to implement this directive, so Belgium is assumed to be representative for the European audit market; and (ii) we are not aware of other studies using proprietary pre-disclosure audit fee data in a European setting.

\footnotetext{
${ }^{4}$ Chapter $\mathrm{X}$ of the directive - Special provisions for the statutory audits of public-interest entities - contains requirements such as the publication of a transparency report by the auditor (audit firm) of the public interest entity, the requirement to have an audit committee, rules of independence, and quality control.

${ }^{5}$ Belgian firms that exceed the size criteria discussed in footnote 6 are considered to be large (cf. 4.2. Belgian Audit Market).
} 


\subsection{Belgian audit market}

In the Belgian audit market, the vast majority of clients are privately owned firms that are generally small compared with those of other industrialized countries (Willekens \& Achmadi, 2003). That is, because of a very small Belgian stock market (Weets \& Jegers, 1997), the private client segment of the Belgian audit market is predominant. In Belgium, not only publicly held firms, but also private firms that exceed certain size criteria ${ }^{6}$ are required to have their annual financial statements externally audited. As a result, many relatively small private Belgian firms are legally required to appoint a statutory auditor (Willekens \& Achmadi, 2003; Van Caneghem, 2010). Belgian firms have to appoint an auditor, who is a member of the Belgian Institute of Registered Auditors, for a three-year period, during which the audit fee is fixed ${ }^{7}$. After the three-year mandate, the same auditor can be re-appointed for another three-year period. For private firms (unlike public interest entities), there are no restrictions regarding the length of the client-auditor relationship (except for the fact that a mandate is always for a threeyear period), so the number of re-appointments is not restricted for the firms in our sample. Audit clients that want to replace their auditor or need to appoint an auditor for the first time must take the initiative and contact potential auditors since solicitation is prohibited in Belgium (and advertising is subject to restrictions).

In addition, the market share of Big 4 auditors, and audit market concentration in general, is less pronounced in Belgium than in other countries (Weets \& Jegers, 1997; Willekens \& Achmadi, 2003; Van Caneghem, 2010; Breesch, De Muylder, \& Hardies, 2012). For example, the majority of Belgian firms (about 54 percent) are audited by a non-Big 4 auditor (Van

\footnotetext{
${ }^{6}$ During the time frame of our study, limited-liability companies are required to appoint a statutory auditor if (i) they have more than 100 employees; or (ii) they exceed at least two of the following size criteria: (a) total assets $>€ 3,650,000$; (b) turnover $>€ 7,300,000$; and/or (3) number of employees $>50$ (Company Code art. $15 \S 1$ ).

${ }^{7}$ If approved by both the annual meeting of shareholders and the auditor beforehand, an annual consumer price index (CPI) adjustment of the audit fee is allowed in the second and third year of the mandate. Other audit fee adjustments during the threeyear mandate are only allowed in exceptional circumstances (e.g., a substantial change in complexity of the engagement) and after approval by both parties.
} 
Caneghem, 2010). Using private client data, Dutillieux and Willekens (2009) document that the Big 4 market share (based on audit fees) within industry groups ranges between 55 percent and 82 percent. However, they state that for the smallest 80 percent of firms in their sample, the Big 4 market share is not larger than $60 \%$, whereas for the largest 20 percent of firms, the Big 4 receive 80 percent of those firm's audit fees (Dutillieux \& Willekens, 2009). In addition, supplier concentration as measured by the Hirschman-Herfindahl index is 0.143 on average (Dutillieux, Stokes, \& Willekens, 2013). For example, Dutillieux and Willekens (2009) document that most of their specified industries are mildly concentrated (HHI between 0.10 and 0.18), whereas three out of 12 industries are highly concentrated (HHI higher than 0.18 ).

\section{Research design}

\subsection{Sample selection and data}

Because 2007 is the initial year of mandatory public disclosure of audit fees in Belgium, we collected data for accounting years 2004, 2007, and 2010 (cf. Section 5.5 Disclosure effect). We did not collect data for the intermediate years for two reasons. First, Belgian companies have to appoint an auditor for a mandated three-year period, during which time the audit fee is fixed (cf. Section 4.2 Belgian audit market). By only collecting data for one year within each of the three-year mandate periods we are certain that we capture audit fee adjustments across the different mandate periods. Second, because of the time-consuming nature of our data collection, which required manual gathering of audit fees and auditor data, we only focused on accounting years 2004, 2007, and $2010^{8}$. Even before mandatory public disclosure of audit fees, Belgian auditors (audit firms) had to submit an annual filing to the Belgian Institute of Registered Auditors that contains the following information (for each engagement): the client's name and unique company number, name of the audit partner, practice of a joint audit (and if

\footnotetext{
${ }^{8}$ The annual filings of all Belgian auditors to the Belgian Institute of Registered Auditors are only available on hard copy. We had to copy all the necessary documents, scan the copies, and convert the scanned copies from a PDF to an Excel file.
} 
so, the name of the joint audit partner), and the audit fee charged. Relying on these annual filings, we are able to address our research questions using both pre- and post-disclosure data (i.e., although audit fees for 2004 are not publicly available, we were able to collect them based on these annual filings $\left.{ }^{9}\right)$. We collected clients' statutory financial statement data from the BelFirst database ${ }^{10}$. Based on the client's unique company number, we could easily match the audit fee and auditor data with clients' financial statement data.

Table 1 presents the sample selection process. We start with audit fee data retrieved from auditors' annual filings at the Belgian Institute of Registered Auditors and match clients' financial statement data obtained from the Bel-First database to audit fee and auditor data. Next, we exclude observations with negative or null audit fees, observations without industry data, and/or missing data to compute all necessary variables. Financial institutions, holding companies, and insurance companies are excluded from the sample. ${ }^{11}$ Finally, the focus of our study are private companies, so we exclude listed companies from our sample. ${ }^{12} \mathrm{We}$ obtain an unbalanced sample containing 35,194 firm-year observations. However, we require clients to have matched observations for the entire study period, so consequently we use a balanced

\footnotetext{
${ }^{9}$ In the years prior to the mandatory disclosure regulation, voluntary disclosure of audit and non-audit fees was not possible in the financial statements because Belgian companies have to file their financial statements using a prescribed format in which there was no code included to record the (non-)audit fee charged by the auditor. In 2007, when the disclosure regulation became applicable, a new prescribed format of the financial statements was introduced, including new codes for the (non-)audit fee paid to the auditor.

${ }^{10}$ Bel-First is a database of Bureau Van Dijk (http://www.bvdinfo.com) containing financial statement information for public and private companies in Belgium and Luxembourg.

${ }^{11}$ This is consistent with prior literature (see e.g., Simunic, 1980; Francis, 1984) and is inspired by the fact that these sectors are subject to other legislation and because some of the empirical proxies employed in the traditional audit fee models (e.g., financial leverage, current or quick ratio, inventory, and trade receivables scaled by total assets) are not meaningful for these sectors (Fields, Fraser, \& Wilkins, 2004).

${ }^{12}$ By focusing on the private client segment of the audit market (rather than the public client segment, or both segments), confounding effects resulting from other regulation that came into effect during the same timeframe as the mandatory audit fee disclosure regulation are limited. Consequently, the impact of the directive on audit effort (and consequently audit pricing) was possibly larger for audits of public clients relative to private clients. In addition, other European and Belgian regulations came into effect around the same period as the audit fee disclosure regulation. For example, the European Parliament and the Council agreed that International Accounting Standards (IAS) (later on International Financial Reporting Standards, IFRS) would apply to the consolidated financial statements of all EU public firms from January 2005 onwards. Also, in April 2010, Belgium implemented a standard and the application of ISA became mandatory for all audits of public interest entities (i.e., public firms, financial institutions, and insurance companies) from December 2012 onwards. For all other Belgian entities, the ISA regulation came into effect from December 2014 onwards.
} 
sample that has 6,313 firm (or 18,939 firm-year) observations. To avoid the potential impact of outliers, we winsorize all continuous variables at the top and bottom 1 percent level.

[ Insert Table 1 here ]

\subsection{Model}

Based on Simunic (1980), we specify an audit fee model containing explanatory variables consistent with prior (Belgian) audit fee literature (Willekens \& Achmadi, 2003; Hay et al., 2006; Van Caneghem, 2010). To test our hypotheses, year dummies, a proxy for client bargaining power, and a test variable that is designed to capture competitive pressure are included. We also include industry dummies. Specifically, we run the following ordinary least square regression (main model):

$$
\begin{aligned}
\text { LnFee } & =\alpha_{1}+\alpha_{2} \text { Year }+\alpha_{3} \text { ClientBargainingPower }+\alpha_{4} \text { CompetitivePressure } \\
& +\alpha_{5} \text { Size }+\alpha_{6} \text { InvRec }+\alpha_{7} \text { Current }+\alpha_{8} \text { Lev }+\alpha_{9} \text { Loss }+\alpha_{10} \text { YearEnd } \\
& +\alpha_{11} \text { Joint }+\alpha_{12} \text { Big } 4+\alpha_{13} \text { IndustryPortfolioShare }+\alpha_{14} \text { Herf Index } \\
& +\alpha_{15} \text { Suppliers }+ \text { Industry dummies }+\varepsilon
\end{aligned}
$$

(Equation 1)

Definitions of all variables in Equation 1 are provided in Table 2.

[ Insert Table 2 here ]

To test H1, we add the interaction terms between ClientBargainingPower and the year dummies to the basic model:

$$
\begin{aligned}
\text { LnFee } & =\alpha_{1}+\alpha_{2} \text { Year }+\alpha_{3} \text { ClientBargainingPower }+\alpha_{4} \text { CompetitivePressure } \\
& +\alpha_{5} \text { ClientBargainigPower } * \text { Year } \\
& +\alpha_{6} \text { Size }+\alpha_{7} \text { InvRec }+\alpha_{8} \text { Current }+\alpha_{9} \text { Lev }+\alpha_{10} \text { Loss }+\alpha_{11} \text { YearEnd } \\
& +\alpha_{12} \text { Joint }+\alpha_{13} \text { Big } 4+\alpha_{14} \text { IndustryPortfolioShare }+\alpha_{15} \text { HerfIndex } \\
& +\alpha_{16} \text { Suppliers }+ \text { Industry dummies }+\varepsilon
\end{aligned}
$$

(Equation 2)

To test $\mathrm{H} 2$, we add the add the interaction terms between CompetitivePressure and the year dummies to the basic model: 


$$
\begin{aligned}
\text { LnFee } & =\alpha_{1}+\alpha_{2} \text { Year }+\alpha_{3} \text { ClientBargainingPower }+\alpha_{4} \text { CompetitivePressure } \\
& +\alpha_{5} \text { CompetitivePressure } * \text { Year } \\
& +\alpha_{6} \text { Size }+\alpha_{7} \text { InvRec }+\alpha_{8} \text { Current }+\alpha_{9} \text { Lev }+\alpha_{10} \text { Loss }+\alpha_{11} \text { YearEnd } \\
& +\alpha_{12} \text { Joint }+\alpha_{13} \text { Big } 4+\alpha_{14} \text { IndustryPortfolioShare }+\alpha_{15} \text { HerfIndex } \\
& +\alpha_{16} \text { Suppliers }+ \text { Industry dummies }+\varepsilon
\end{aligned}
$$

(Equation 3)

Because we use balanced panel data containing the same firm more than once, clustering may occur and affect our estimates. Therefore, we use the robust cluster technique as suggested by Petersen (2009) to control for firm-level clustering and heteroscedasticity.

In what follows, we discuss our sample split of clients with positive versus negative abnormal audit fees and variables in more detail.

\subsection{Positive versus negative abnormal audit fees}

Consistent with prior studies (Francis \& Wang, 2005; Choi, Kim, \& Zang, 2010; Asthana \& Boone, 2012; Blankley, Hurtt, \& MacGregor, 2012), we use audit fee residuals to distinguish between clients with positive and negative abnormal audit fees. Thus, to test our hypotheses, we start by estimating Equation 1 for each year separately. The estimated residuals capture unexplained variance in audit fees after controlling for client/auditor/engagement characteristics, so positive (negative) residuals capture clients with a positive (negative) abnormal audit fee.

\subsection{Auditfees}

Since we cover a seven-year period in our main analyses, we adjust for movements in price levels (i.e., inflation). In particular, we correct audit fees for movements in the Belgian Consumer Price Index (CPI $)^{13}$. The dependent variable of audit fees in the audit fee models

\footnotetext{
${ }^{13}$ The CPI was 108.4 in 2007 and 115.0 in 2010, relative to 100 in 2004 (reference year).
} 
defined in Equations 1, 2, and 3 is LnFee, the natural logarithm of inflation-adjusted audit fees $^{14}$.

\subsection{Disclosure effect}

As discussed in the sample selection, we use data for accounting years 2004, 2007, and 2010. Belgium implemented the requirement for public disclosure of audit fees in financial statements for the accounting year ending on June 30 from 2007 onwards. Consequently, accounting year 2004 is the pre-disclosure year. Audit fees from accounting year 2004 relate to a period well before the requirement came into effect and are, therefore, unaffected by the disclosure regulation. In the initial disclosure year (2007), mandatory disclosure might have already had an impact (limited and anticipatory) on the pricing of audit services. That is, in 2006, the European Parliament and the Council announced the introduction of mandatory audit fee disclosure and in Belgium the Directive was enacted in April 2007. Consequently, in 2006 (the pre-disclosure period) auditors are already likely to be aware which clients in their portfolio are over- or undercharged (e.g., by performing an analysis of audit fees in their own portfolio). Once audit fees become publicly available, clients are able to compare fees of auditorcompetitors to other clients in the market; i.e., a client can now evaluate whether they are overor undercharged relative to other clients in the market. ${ }^{15}$ To avoid difficult negotiations with over- or undercharged clients, auditors might strategically act and (partially) adjust audit fees before they become publicly available.

\footnotetext{
${ }^{14}$ As reported in the sensitivity analyses, results are similar when we do not adjust for CPI.

${ }^{15}$ After public disclosure of audit fees, clients can rather easily benchmark their audit fee with that paid by one or more of their close competitors. In the Belgian context, financial statements which disclose the audit fee paid are publicly and freely available through the website of the National Bank of Belgium. While clients are unlikely to use audit fee models to determine whether they are over- or undercharged, they are likely to control for competitor size (which is the most important determinant in empirical audit fee models) when comparing their audit fee with that paid by their peers. Auditors, just like other professional users of financial statements (e.g., banks), are likely to have a subscription to the Belfirst database (containing financial statement data for Belgian companies and organizations, including audit fees for the post-disclosure period) enabling them to easily benchmark audit fees.
} 
In sum, although audit fees might be unaffected by the mandatory disclosure regulation in the initial disclosure year, we expect to observe some anticipatory strategic behavior by auditors in setting audit fees to more acceptable levels (i.e. downward (upward) audit fee adjustment for overcharged (undercharged) clients). In accounting year 2010, fully representing the post-disclosure period, the impact of mandatory disclosure of audit fees on audit pricing is expected to be the largest since all audit engagements were able to renegotiate fees after the three-year mandate by using publicly observable audit fees.

To capture the impact of mandatory disclosure of audit fees on subsequent audit pricing, we include year dummies for financial years 2007 (Y2007) and 2010 (Y2010) in our model, with 2004 serving as the reference year.

\subsection{Client bargaining power}

As stated in H1, we expect clients with positive (negative) abnormal audit fees and higher bargaining power to be able to negotiate fees more downward (less upward) relative to clients with lower bargaining power. ClientBargainingPower is measured as the ratio of the client's total assets over the sum of total assets for all companies in the same Belgian region audited by the company's auditor (Fung, Gul, \& Krishnan, 2012) ${ }^{16}$. We split Belgium into three regions as geographical markets in which auditors compete: Flemish Region, Brussels Capital Region,

\footnotetext{
${ }^{16}$ In prior literature (Casterella et al., 2004; Nagy, 2005; Huang, Raghunandan, \& Rama, 2009; Fung et al., 2012), client bargaining power is typically measured by the ratio of the natural logarithm of the client's sales to the sum of sales of all companies in the same industry audited by the client's auditor. As a robustness check, Fung et al. (2012) also rely on clients' total assets to measure client bargaining power, and their results are not affected by using this proxy. Since clients' sales are not available for many observations in our sample, we used total assets instead to capture bargaining power. As discussed in Section 4 (i.e., Institutional setting), only firms that meet certain size criteria are required to appoint an auditor. Our sample includes firms that do not meet these size criteria, but nevertheless voluntarily appoint an auditor. These clients file their financial statements using an abbreviated format in which the sales figure does not have to be disclosed.
} 
and Walloon Region ${ }^{17}$. An audit market is defined as a Nace-BEL industry ${ }^{18}$ in a Belgian region. We add an interaction term between the year dummies and ClientBargainingPower to capture the impact of client bargaining power on audit fee adjustments subsequent to mandatory audit fee disclosure. Based on $\mathrm{H} 1$, we expect a negative coefficient for ClientBargainingPower*Year, suggesting that from disclosure onwards, clients with higher bargaining power are able to negotiate a more favorable fee adjustment.

\subsection{Competitive pressure}

Competitive pressure (CompetitivePressure) is defined based on Numan and Willekens (2012a) as the smallest absolute market share difference (based on audit fees) between an incumbent auditor and the closest competitor. In line with Numan and Willekens (2012b), and to facilitate interpretation of our results, we take the negative value of this absolute distance. We expect this measure to have a negative coefficient; that is, the nearer the closest competitor in terms of industry market share distance, the higher the competitive pressure for the incumbent auditor. This is likely to put pressure on auditor bargaining power. We add an interaction term between the year dummies and CompetitivePressure to measure the impact of the mandatory disclosure regulation on audit fee adjustments in more competitive segments of the audit market (i.e., segments in which competitive pressure of the closest competitor is high(er)). In line with $\mathrm{H} 2$, we expect a negative coefficient for CompetitivePressure*Year. From mandatory disclosure onwards, auditors who face lower bargaining power because of

\footnotetext{
${ }^{17}$ Belgium is a federal monarchy with a federal government and is divided into three regions (Flemish Region, Walloon Region, and Brussels Capital Region). Each region has political power regarding matters such as the economy, employment, and agriculture. Political differences as well as language barriers across regions can give rise to differences in competition (Dekeyser, Gaeremynck, \& Willekens, 2014). That is, in addition to the three Regions, Belgium has three Communities which are divided based on the "spoken language." Belgium has three official languages: Dutch, French, and German. This results in Flemish, French, and German-speaking Communities.

18 The following industries are discerned: (1) manufacturing; (2) construction; (3) wholesale and retail trade, repair of motor vehicles and motorcycles; (4) transportation and storage; (5) information and communication; (6) financial and insurance activities; (7) real estate activities; (8) professional, scientific and technical activities; (9) administrative and support service activities; and (10) other. Industry 10 serves as the reference category in our model, and industry 6 is excluded.
} 
higher competitive pressure find themselves in a weaker position for negotiating a more favorable fee adjustment.

\subsection{Control variables}

Following prior audit fee research, we include several control variables (see Hay et al. (2006) for a detailed motivation regarding the inclusion of these variables). To control for client characteristics, we include the natural logarithm of total assets (Size), the ratio of inventory and receivables over total assets $(\operatorname{InvRec})$, the current ratio (Current), the ratio of total debts over total assets (Lev), and a dummy variable that captures a loss (Loss). We control for engagement characteristics by including a dummy variable for December year-ends (YearEnd) and joint audits (Joint) (see Bianchi (2018) for a good discussion of the potential effects of a joint audit). We also include a Big4 dummy variable. We include IndustryPortfolioShare as a proxy for auditor's industry expertise to capture auditor's market power towards the client. IndustryPortfolioShare is defined as the total amount of audit fees generated by an audit firm in an industry as a percentage of total audit fees generated by that audit firm in a Belgian region. In line with Numan and Willekens (2012a), we include the Herfindahl index (HerfIndex), based on audit fees per audit market, as a variable to control for market concentration (see also Pearson and Trompeter (1994)) and Suppliers as a proxy for the number of audit firms active in an audit

market. As the number of suppliers increases, we expect the distance between competing suppliers to decrease; that is, an increase in competitive pressure results in lower audit fees. Following Van Caneghem (2010), we include nine industry dummy variables based on NaceBEL codes (see footnote 18).

\section{Results and discussion}

\subsection{Descriptive statistics}


Descriptive statistics for our balanced sample are presented in Table 3. Audit fees (Fees) have a mean (median) value of $€ 11,669(€ 6,157)$. The average (median) client size in terms of total assets equals $€ 40.35$ million ( $€ 7.19$ million). On average, 49.4 percent of the clients in our sample are audited by a Big 4 auditor. Note that the average number of listed clients in the full balanced sample before excluding listed firms is less than 1 percent, demonstrating that the Belgian audit market is dominated by the private client segment (cf. Section 4. Institutional setting).

\section{[ Insert Table 3 here ]}

Table 4 presents descriptive statistics for each sample year separately. We always performed a t-test to test for potential differences in the variables over time (see last column in Table 4). As in prior studies (e.g., Francis \& Wang, 2005; Carson, Redmayne, \& Liao, 2014), audit fees increased over time from $€ 10,768$ in 2004 , to $€ 11,823$ in 2007 and to $€ 12,415$ in $2010^{19}$, on average. This increase in audit fees might be caused by an overall increase in audit risk as a result of the financial crises, which is then charged to the client. Carson et al. (2014) also observe an increase in audit fees in the Australian market from 2000 to 2011. They argue that this increase can be attributed to increased regulation because audit effort to complete audit engagements increases in times of regulatory change and during financial crises.

\section{[ Insert Table 4 about here ]}

We also note an increase in client size in terms of total assets. The mean (median) client size increases from $€ 34.78$ million ( $€ 6.27$ million) in 2004 , to $€ 41.59$ million ( $€ 7.58$ million) in 2007, and to $€ 44.67$ million ( $€ 7.86$ million) in 2010. Note that ClientBargainingPower decreases, on average, over the study period. Although the median of CompetitivePressure remains quite stable over time (-0.006 in 2004, -0.004 in 2007 and -0.005 in 2010), we observe a decrease in its mean value in 2010 (-0.022) relative to 2004 (-0.013). Remarkably, the number

\footnotetext{
${ }^{19}$ We observe a similar trend for audit fees that are not CPI-adjusted: $€ 10,831$ in 2004, $€ 12,818$ in 2007 , and $€ 14,191$ in 2010.
} 
of clients audited by a Big 4 auditor decreases over the study period, with a substantial drop in 2007 relative to 2004 (from 52.7 percent to 48.4 percent). Note that the number of suppliers of audit services (measured at audit firm level) active in the Belgian audit market also decreases over time, with the largest drop in 2010 (mean of 101) relative to 2007 (mean of 107). Untabulated descriptive statistics for the unbalanced sample show an increase in the number of client observations over the study period. Thus, although the number of clients in need of an auditor increases, we observe in both the unbalanced and balanced sample a decrease in the number of auditors (i.e., the supply side of the audit market). This finding suggests a competitive market in which entry is challenging.

\subsection{Correlation matrix}

Table 5 presents Pearson correlations for the variables in Equation 1. Our test variables ClientBargainingPower and CompetitivePressure are significantly and negatively correlated with LnFees. This is in line with our expectations and prior studies (Casterella et al., 2004; Numan \& Willekens, 2012a). Clients with higher bargaining power pay lower audit fees than clients with lower bargaining power. The higher the competitive pressure faced by an incumbent auditor from the closest competitor in terms of industry market share distance, the lower the audit fee. The magnitude of the correlations between the independent variables does not suggest multicollinearity problems as all correlations among the independent variables are well below 0.60. Nevertheless, we also considered variance inflation factors (VIF) for all regression models. A VIF higher than 10 indicates that multicollinearity may be unjustifiably influencing the least squares estimates (Neter, Wasserman, \& Kutner, 1989: 409). No VIF approaches this level, with the highest being 5.37. Consequently, our results do not appear to be influenced by multicollinearity.

[ Insert Table 5 here ] 


\subsection{Multivariate analyses}

\subsubsection{Main model}

Table 6 reports results for the audit fee model defined in Equation 1. The results are presented for the full balanced sample as well as for each year separately. Overall, we observe a marked increase in the explanatory power of our models over time (i.e., $\mathrm{R}^{2}$ increases from 0.4323 for 2004 to 0.5288 for 2010 ), suggesting an increase in audit pricing precision that can be attributed to the audit fee disclosure regulation. A Vuong (1989) Z-statistic (Barth, Cram, \& Nelson, 2001; Wooldridge, 2010) to test whether the difference in explanatory power over the years is significant, confirms this result.

\section{[ Insert Table 6 about here ]}

Based on the full balanced sample, year dummies for both 2007 and 2010 are significantly positive at $\mathrm{p}<0.001$, suggesting an overall increase in audit fees over time. This finding is in line with the descriptive statistics previously discussed. The coefficient for ClientBargainingPower is significantly negative based on the full balanced sample and in the separate year models, except for the model based on accounting year 2004. The coefficient for ClientBargainingPower only becomes significantly negative from accounting year 2007 onwards. This suggests that clients gained bargaining power from mandatory disclosure onwards, which is in line with our expectations and intuitive results from Francis and Wang (2005) and Su and Wu (2017). The coefficient for CompetitivePressure is significantly negative based on the full balanced sample, as well as in the model for accounting year 2010, suggesting increased competitive pressure in the period subsequent to the disclosure regulation. While this fits our expectations, we do not observe this competition effect in the initial disclosure year 2007. The coefficient for IndustryPortfolioShare increases in accounting year 2007 relative to 2004, but experiences a big drop in 2010 relative to 2007. We observe the same trend for Big4. 
Both the drop in the coefficient for IndustryPortfolioShare and Big4 suggest that in the years subsequent to disclosure, auditors face a decrease in auditor bargaining power. This outcome is in line with our expectations.

In the full balanced sample as well as in the separate year models, coefficients for almost all other control variables fit expectations. The exceptions are YearEnd, where the coefficient is significantly negative (except in year 2004), and Joint, whose coefficient is not statistically significant.

\subsubsection{Disclosure effect}

Before testing $\mathrm{H} 1$ and $\mathrm{H} 2$, we verify whether our results confirm results of prior studies based on public firms (Francis \& Wang, 2005; Su \& Wu, 2017). Results of the Equation 1 audit fee model are presented in Table 7. To test the impact of mandatory disclosure on audit pricing in the initial (and subsequent) disclosure year, we run our regression using data for accounting years 2004 and 2007 separately from the regression including data for accounting years 2007 and 2010. In line with $\mathrm{Su}$ and $\mathrm{Wu}$ (2017), we expect audit fee adjustments to be more pronounced in the post-disclosure period.

\section{[ Insert Table 7 about here ]}

In the full balanced samples, $Y 2007$ and $Y 2010$ are both significantly positive at $\mathrm{p}<0.001$, indicating an increase of audit fees over time. This finding is consistent with results reported in Table 6 and with descriptive statistics. Furthermore, we report results when the sample is split between clients with positive versus negative abnormal audit fees. For clients with positive abnormal audit fees, coefficients for $Y 2007$ and $Y 2010$ are significantly negative at $\mathrm{p}<0.001$ in both models. This outcome suggests a downward audit fee adjustment for clients with positive abnormal audit fees in both the pre- and post-disclosure period. Clients with negative abnormal audit fees face an upward fee adjustment, as indicated by the significantly positive 
coefficients with $\mathrm{p}<0.001$ for $Y 2007$ and $Y 2010$. An F-test indicates that the coefficients of Y2007 and Y2010 in the 2004/2007 (2007/2010) model of both subsamples are significantly different from each other.

However, Table 7 reveals that audit fee adjustments resulting from mandatory disclosure are largest in the initial disclosure year 2007 for both clients with positive and negative abnormal audit fees, which might suggest anticipatory price adjusting behavior by auditors. Specifically, auditors of clients with positive abnormal audit fees might have adjusted the audit fee downward before mandatory disclosure came into effect to reduce the likelihood that the client would switch auditors as soon as a comparison of audit fees charged by the auditor across different clients is possible. For clients with negative abnormal audit fees, the auditor might have adjusted the audit fee upward before mandatory disclosure because in competitive audit markets, such as the private client segment, it might be difficult to increase abnormally low audit fees once the audit fees become publicly available. This anticipatory pricing behavior by auditors might be caused by the prevalence of price competition in the private client segment of the market for audit services (see Simunic, 1980).

\subsubsection{Client bargaining power $(\mathrm{H} 1)$}

In Table 8, we report results for the audit fee model defined in Equation 2. In the full balanced samples, Y2007 and Y2010 are again both significantly positive at $\mathrm{p}<0.001$. Next, the sample is split between clients with positive versus negative abnormal audit fees. Similar to the results reported in Table 7, we observe significantly negative (positive) coefficients for the year dummies for clients with positive (negative) abnormal audit fees.

\section{[ Insert Table 8 about here ]}

To test H1, we focus on the interaction terms between ClientBargainingPower and the year dummy variables in the sub-samples of clients with positive and negative abnormal audit 
fees. For the sub-sample of clients with positive abnormal audit fees, coefficients for ClientBargainingPower*2007 and ClientBargainingPower*2010 are not statistically significant. These results suggest that regardless of their bargaining power, those clients face a downward fee adjustment from disclosure onwards, which is largest in 2007, the initial disclosure year. In the sub-sample of clients with negative abnormal audit fees, however, we find that clients with higher bargaining power are able to mitigate the upward fee adjustment subsequent to disclosure. That is, in the models for clients with negative abnormal audit fees, the coefficients for ClientBargainingPower*2007 and ClientBargainingPower*2010 are significantly negative at $\mathrm{p}<0.01$. Therefore, we find support for $\mathrm{H} 1$, albeit only for clients with negative abnormal audit fees. The observation that client bargaining power only matters for upward audit fee adjustments could be explained by an upward fee adjustment being difficult for the client to accept (unlike a downward adjustment of the audit fee). Accordingly, in case of an upward audit fee adjustment, clients are more likely to fully exploit their bargaining power.

\subsubsection{Competitive pressure $(\mathrm{H} 2)$}

Table 9 reports results for the Equation 3 audit fee model in which we add the interaction terms between CompetitivePressure and the year dummies. These models are aimed at testing $\mathrm{H} 2$, the effect of competitive pressure on audit fee adjustments after public disclosure, so we report results for clients with positive and negative abnormal audit fees separately. Again, we observe a significantly negative (positive) coefficient for year dummies 2007 and 2010 for clients with positive (negative) abnormal audit fees. For the sub-sample of clients with positive abnormal audit fees, the coefficient for CompetitivePressure $* 2007$ is not statistically significant while the coefficient of CompetitivePressure*2010 is significantly positive. This positive coefficient suggests that clients with an auditor who faces fierce competition have higher audit fees. This is not in line with our expectations. 


\section{[ Insert Table 9 about here ]}

For the sub-sample of clients with negative abnormal audit fees, however, coefficients for both CompetitivePressure*2007 and CompetitivePressure*2010 are significantly negative. These results suggest that clients with negative abnormal audit fees and with an auditor who faces higher pressure from competitors nearby are able to mitigate the upward fee adjustment subsequent to disclosure.

Therefore, we find support for $\mathrm{H} 2$, albeit only for clients with negative abnormal audit fees. So, in line with results obtained for client bargaining power, we find that competitive pressure only matters for upward audit fee adjustments. Again, an upward fee adjustment might be difficult for the client to accept (unlike a downward adjustment of the audit fee) and, therefore, hinder the audit fee negotiation process. An incumbent auditor who faces fierce competitive pressure might be aware that the client can easily switch to an auditor who provides the same quality. This competitive pressure from similar auditors in the market reduces the auditor's bargaining power with the client. Therefore, the auditor might not be able to increase the audit fee as much as desired. In addition, we observe this effect in favor of the client to be largest in the initial disclosure year.

\subsection{Additional analyses}

\subsubsection{Big 4 vs. non-Big 4 clients}

In line with Corbella et al. (2015) and others, we also perform a sample split between clients that do and do not have a Big 4 auditor. Doing so, we are able to assess whether the impact of audit fee disclosure is different for Big 4 clients compared to non-Big 4 clients (Corbella et al., 2015). ${ }^{20} \mathrm{We}$ estimate the models in Tables 7 to 9 for the four subsamples: (i) Big 4 clients with a positive abnormal audit fee; (ii) Big 4 clients with a negative abnormal audit fee; (iii) non-Big 4 clients with a positive abnormal audit fee; and (iv) non-Big 4 clients

\footnotetext{
${ }^{20}$ Corbella et al. (2015) show that the effects of audit firm rotation, in terms of audit fee and audit quality effects, differ between Big 4 and non-Big 4 clients.
} 
with a negative abnormal audit fee. Untabulated results reveal some differences relative to the results reported in Tables 7 to 9. First, the coefficients for ClientBargainingPower $* 2007$ and ClientBargaingPower $* 2010$ are significantly negative in the subsample of non-Big 4 clients with a positive abnormal audit fee. This result suggests that client bargaining power matters for non-Big 4 clients with positive abnormal audit fees in negotiating a more downward fee adjustment and differs from our results in Table 8.

Second, the coefficient for CompetitivePressure*2010 is significantly negative for the subsamples of non-Big 4 and Big 4 clients having a positive abnormal audit fee, which we do not observe in Table 9. This finding suggests that clients with positive abnormal audit fees and an auditor who faces fierce competition are able to negotiate a more favorable (lower) fee in the period subsequent to the mandatory disclosure regulation. This is consistent with our prior expectations for $\mathrm{H} 2$. Third, in the subsample of Big 4 clients with a negative abnormal audit fee, ClientBargainingPower*2007 and ClientBargainingPower*2010 are no longer significant. Finally, in the subsample of non-Big 4 clients with a negative abnormal audit fee, the coefficients for ClientBargainingPower*2007 and CompetitivePressure*2007 are not statistically significant.

Altogether, results from these additional analyses reveal that upward audit fee adjustments are not affected by client bargaining power among Big 4 clients, although they are for non-Big 4 clients. As such, negotiating an upward fee adjustment appears more difficult for non-Big 4 auditors. This is in line with Big 4 clients being more likely to be quality-seeking and Big 4 auditors being able to convince their clients that they provide an audit service of higher quality than other auditors in the market (cf. Section 2. Literature review).

\subsubsection{Initial audit engagements}


Because of competition in the audit market, tendering over audit engagements may lead to low balling (e.g., DeAngelo, 1981; Coate \& Loeb, 1997; Cameran, 2005). Based on their meta-analysis of the audit fee literature, Hay et al. (2006) find support for the assertion that audit fees are usually lower in audits where the auditor is relatively new to the engagement. To test whether initial audit engagements (auditor changes) affect our results, we perform two additional tests. First, we run all models reported in Tables 7 to 9 including a dummy variable Initial equal to 1 if the client changed auditor in the current period relative to the previous period, and 0 otherwise. Untabulated results are similar to those reported in Tables 7 to 9 . Second, in line with Pearson and Trompeter (1994) and others, we run all models reported in Tables 7 to 9 separately for: (i) the sub-sample of clients who did not switch their auditor; and (ii) the sub-sample of clients who changed their auditor. Untabulated results are similar to those reported in Tables 7 to 9. However, in both subsamples of clients with negative abnormal audit fees, ClientBargainingPower $* 2010$ is no longer significantly negative in the 2007/2010 model.

\subsection{Sensitivity analyses}

\subsubsection{Non-inflation-adjusted audit fees}

We estimated all models (including the additional analyses) using non-CPI-adjusted audit fees to determine whether our results are influenced by the CPI adjustment. In general, results are consistent with those reported in Tables 6 to 9. However, unlike Tables 8 and 9, the coefficient for $Y 2010$ is not statistically significant in the models for clients with positive abnormal audit fees when relying on non-CPI-adjusted audit fees.

\subsubsection{Positive versus negative abnormal audit fees}

In our main analyses we use the residuals of Equation 1 to split our balanced sample into clients with positive versus negative abnormal audit fees. We performed two additional tests to 
assess the robustness of this procedure. First, we estimate all models reported in Tables 7 to 9 using a reduced sample in which we only consider extreme values of both positive and negative abnormal audit fees, i.e. observations for which audit fee residuals are more than one standard deviation away from the mean. Untabulated results are similar to those reported in Tables 7 to 9, except for the interaction terms ClientBargainingPower*2007 and ClientBargainingPower*2010 is no longer statistically significant for clients with negative abnormal audit fees and CompetitivePressure $* 2010$ is no longer significant for clients with positive abnormal audit fees. Therefore, results suggest that client bargaining power does not affect the upward audit fee adjustment for extremely negative abnormal audit fees.

Second, instead of considering residuals, we run the Equation 1 audit fee model for accounting year 2001 (2004) and use the coefficients from that model to predict audit fees for 2004 (2007). Next, we compare the predicted values with the actual audit fees of 2004 (2007) to distinguish between clients with positive abnormal audit fees and those with negative abnormal audit fees. Employing this alternative approach, untabulated results are similar to those reported in Tables 7 to 9, with two exceptions: (i) ClientBargainingPower $* 2007$ is significantly negative in the sub-sample of clients with positive abnormal audit fees for the 2004/2007 model; and (ii) CompetitivePressure*2010 is no longer statistically significant for clients with negative abnormal audit fees for the 2007/2010 model.

\subsubsection{Truncation at 5 percent level}

Because some firm-level variables are still skewed after winsorization at the 1 percent level (cf. Tables 3 and 4), we replicated our analyses after truncating the continuous firm-level variables at the top and bottom 5 percent. We do so to ensure that our results are not driven by

outliers. Results (untabulated) are similar to those reported in Tables 7 to 9, with two exceptions: (i) ClientBargainingPower*2010 is no longer statistically significant for clients 
with negative abnormal audit fees for the 2007/2010 model; and (ii) CompetitivePressure $* 2010$ is no longer statistically significant for clients with positive abnormal audit fees for the 2007/2010 model.

\section{Conclusion}

In this study we examine the effect of mandatory disclosure of audit fees on audit pricing and price competition in the private client segment of the audit market. Specifically, we expect price competition between auditors to intensify after the public disclosure of audit fees because audit fee transparency is likely to increase client bargaining power and/or increase competitive pressure among auditors. Our study contributes to the literature in three important ways. First, we study the role of publicly available information in the pricing of audit services and competitiveness of the audit market. Second, we shed light on audit pricing and price competition in an institutional setting that is dominated by the private client segment. Third, we add to the literature by explicitly considering the effect of both client bargaining power and competitive pressure on audit fee adjustments subsequent to public audit fee disclosure.

We test our predictions using Belgian data for the years 2004 (pre-disclosure), 2007 (initial disclosure year), and 2010 (post-disclosure). We observe an overall increase in audit fees over the seven-year period. Consistent with Francis and Wang (2005) and $\mathrm{Su}$ and $\mathrm{Wu}$ (2017), we observe a downward (upward) fee adjustment for clients with positive (negative) abnormal audit fees from audit fee disclosure onwards. These audit fee adjustments are the largest in 2007, the initial disclosure year, which suggests anticipatory price adjusting behavior by audit firms. Furthermore, our results indicate that upward audit fee adjustments are affected by both client bargaining power and competitive pressure. That is, clients with higher bargaining power or an auditor facing fiercer competition are better able to mitigate the upward fee adjustment compared with other clients. Again, these effects are the largest in the initial 
disclosure year. We find no effect of client bargaining power or competitive pressure on downward audit fee adjustments. Overall, our findings suggest increased price competition and anticipatory price adjusting behavior by auditors due to mandatory audit fee disclosure. Our findings indicate the importance of publicly available information in the pricing of audit services and competition within the audit market. In addition, our findings also increase our understanding of the importance of bargaining power and competitive pressure in the clientauditor relationship. Hence, our paper is of interest to regulators, policy makers, accounting scholars, and clients of audit services.

Results are relevant for regulators and policy makers because they provide insight into the effects of mandatory audit fee disclosure, and thus allows them to assess the effects of this type of regulation. As competition in the market for audit services has been on the agenda of regulators and policy makers for quite some time, observing increased price competition in the post-disclosure period is quite a relevant finding to them. For accounting scholars, findings are relevant as they provide additional insights on factors affecting audit fee increases versus audit fee decreases. As discussed in de Villiers et al. (2014), studies that compare differences between upward and downward audit fee changes are scarce. Our findings add to this strand of literature by demonstrating that the effects of client bargaining power and competitive pressure faced by the auditor are especially relevant in mitigating upward fee adjustments. For audit clients as well, our results provide some interesting takeaways. As an illustration, findings suggest that audit clients might benefit from benchmarking the audit fee and exploiting their bargaining power during audit fee negotiations.

Our study is subject to limitations. We implicitly assume that the year dummies included in our models only capture the disclosure effect. Although we report findings that are consistent with a disclosure effect, there may be other factors affecting the pricing of audit services during the period under study. Because auditors' annual filings at the Belgian Institute of Registered 
Auditors (the source used to collect audit fee data) do not contain non-audit fees, we are unable to control for non-audit fees or the provision of non-audit services in our models. Finally, given our focus on private firms, we are unable to control for governance mechanisms (i.e., governance data are not publicly available in a private firm context). These limitations offer interesting avenues for further research.

In addition to the evidence that public disclosure of audit fees affects price competition in the audit market, the disclosure regulation might also affect audit quality. Increased fee pressure resulting from mandatory audit fee disclosure may negatively affect the level of audit quality provided by auditors. Further research is encouraged to analyze potential changes in audit quality resulting from the disclosure regulation. Public disclosure of audit fees might also affect the way auditors compete, such as a shift from competition in terms of audit quality to competition in terms of audit fees, which also offers a fruitful avenue for further research. 


\section{Acknowledgments}

We would like to thank the editor, two anonymous reviewers, Liesbeth Bruynseels, Simon Dekeyser, Ann Gaeremynck, Robert Knechel, the participants of the 2013 5th EARNet PhD Workshop in Trier, the 2015 Auditing Section Midyear Conference of the AAA in Miami (FL), the 2015 International Symposium on Audit Research in Boston (MA), and seminar participants at KU Leuven for their helpful comments on previous versions of this paper. We gratefully acknowledge data support from the Belgian Institute of Registered Auditors.

\section{Funding}

This research did not receive any specific grant from funding agencies in the public, commercial, or not-for-profit sectors.

\section{References}

Asthana, S. C., \& Boone, J. P. (2012). Abnormal audit fee and audit quality. Auditing: A Journal of Practice \& Theory, 31(3), 1-22. https://doi.org/10.2308/ajpt-10294

Barth, M., Cram, D. P., \& Nelson, K. K. (2001). Accruals and the prediction of future cash flows. The Accounting Review, 76, 27-58. https://doi.org/10.2308/accr.2001.76.1.27

Belleflamme, P., \& Peitz, M. (2010). Industrial Organization: Markets and Strategies. Cambridge, U.K., Cambridge University Press

Bianchi, P. A. (2018). Auditors's joint engagements and audit quality: Evidence from Italian private companies. Contemporary Accounting Research, 35(3), 1533-1577. doi:10.1111/1911-3846.12327

BilReG (2004). Bilanzrechtsreformgesetz, Gesetz zur Einführung internationaler Rechnungslegungsstandards und zur Sicherung der Qualität der Abschlussprüfung vom 4, Dezember 2004, Bundesgesetzblatt Teil I, 3166. 
Blankley, A. I., Hurtt, D. N., \& MacGregor, J. E. (2012). Abnormal audit fees and restatements. Auditing: A Journal of Practice \& Theory, 31(1), 79-96. https://doi.org/10.2308/ajpt-10210

Breesch, D., De Muylder, J., \& Hardies, K. (2012). Concentration in the Belgian audit market: A study based on the annual accounts. Tax Audit \& Accountancy, 35, 6-14.

Cameran, M. (2005). Audit fees and the large auditor premium in the Italian market. International Journal of Auditing, 9, 129-146. https://doi.org/10.1111/j.1099$\underline{1123.2005 .00205 . \mathrm{x}}$

Carlton, D. W., \& Perloff, J. M. (2005). Modern Industrial Organization. Pearson

Carson, E., Redmayne, N. B., \& Liao, L. (2014). Audit market structure and competition in Australia. Australian Accounting Review, 24(4), 298-312. https://doi.org/10.1111/auar.12041

Casterella, J. R., Francis, J. R., Lewis, B. L., \& Walker, P. L. (2004). Auditor industry specialization, client bargaining power, and audit pricing. Auditing: A Journal of Practice \& Theory, 23(1), 123-140. https://doi.org/10.2308/aud.2004.23.1.123

Causholli, M., \& Knechel, W. R. (2012). An examination of the credence attributes of an audit. Accounting Horizons, 26(4), 631-656. https://doi.org/10.2308/acch-50265

Chaney, P. K., Jeter, D. C., \& Shivakumar, L. (2004). Self-selection of auditors and audit pricing in private firms. The Accounting Review, 79(1), 51-72. https://doi.org/10.2308/accr.2004.79.1.51

Choi J.-H., Kim, J.-B., \& Zang, Y. (2010). Do abnormally high audit fees impair audit quality? Auditing: A Journal of Practice and Theory, 29(2), 115-140. https://doi.org/10.2308/aud.2010.29.2.115

Coate, C. J., \& Loeb, M. P. (1997). Audit pricing, auditor changes and the winner's curse. British Accounting Review, 29, 315-334. https://doi.org/10.1006/bare.1997.0054 
Companies Act. 1967. Companies Act, Act 25 of 1967, Appointment and Remuneration of Auditors, U.K.

Corbella, S., Florio, C., Gotti, G., \& Mastrolia, S. A. (2015). Audit firm rotation, audit fees and audit quality: The experience of Italian public companies. Journal of International Accounting, Auditing and Taxation, 25, 46-66.

DeAngelo, L. E. (1981). Auditor independence, 'low balling', and disclosure regulation. Journal of Accounting and Economics, 3(2)August, 113-127. https://doi.org/10.1016/0165-4101(81)90009-4

Dekeyser, S., Gaeremynck, A., \& Willekens, M. (2014). Audit-office industry expertise, audit production, and audit fees. Working paper KU Leuven.

de Villiers, C., Hay, D., \& Zhang, Z. (2014). Audit fee stickiness. Managerial Auditing Journal, 29(1), 2-26. https://doi.org/10.1108/MAJ-08-2013-0915

Dutillieux, W., \& Willekens, M. (2009). The effect of auditor industry specialization on audit pricing in Belgium. Review of Business and Economics, 2, 129-146.

Dutillieux, W., Stokes, D., \& Willekens, M. (2013). Strategic pricing by Big 4 audit firms in private client segments. Accounting and Finance, 53(4), 961-994. https://doi.org/10.1111/acfi.12051

Dye, R. A. (1991). Informationally motivated auditor replacement. Journal of Accounting and Economics, 14, 347-374. https://doi.org/10.1016/0165-4101(91)90008-C

European Parliament and Council (2006). Directive of the European Parliament and of the Council (2006/43/EC) on statutory audits of annual accounts and consolidated accounts, Article 49 - Amendment of Directive 78/660/EEC and Directive 83/349/EEC.

Federation of European Accountants (2016). Pursuing a strategic debate: The future of audit and assurance. Discussion Paper. (FEE, Brussels). Available at: 
https://www.accountancyeurope.eu/wpcontent/uploads/1601_Future_of_audit_and_assurance.pdf (Accessed July 17, 2017).

Fields, L. P., Fraser, D. R., \& Wilkins, M. S. (2004). An investigation of the pricing of audit services for financial institutions. Journal of Accounting and Public Policy, 23(1), 5377. $\underline{\text { doi:10.1016/j.jaccpubpol.2003.11.003 }}$

Francis, J. (1984). The effect of audit firm size on audit prices: A study of the Australian audit market. Journal of Accounting and Economics, 6(2), 133-151. https://doi.org/10.1016/0165-4101(84)90010-7

Francis, J. R., \& Wang, D. (2005). Impact of the SEC's public disclosure requirement on subsequent period fees and implications for market efficiency. Auditing: A Journal of Practice \& Theory, 25(Supplement), 145-160. https://doi.org/10.2308/aud.2005.24.s$\underline{1.145}$

Fung, S. Y. K., Gul, F. A., \& Krishnan, J. (2012). City-level auditor industry specialization, economies of scale, and audit pricing. The Accounting Review, 87(4), 1281-1307. https://doi.org/10.2308/accr-10275

Hay, D. C., \& Knechel, W. R. (2010). The effects of advertising and solicitation on audit fees. Journal of Accounting and Public Policy, 29(1), 60-81. https://doi.org/10.1016/j.jaccpubpol.2009.10.001

Hay, D. C., Knechel, W. R., \& Wong, N. (2006). Audit fees: A meta-analysis of the effect of supply and demand attributes. Contemporary Accounting Research, 23(1), 141-191. https://doi.org/10.1506/4XR4-KT5V-E8CN-91GX

Hay, D. C. (2012). Further evidence from meta-analysis of audit fee research. International Journal of Auditing, 17(2), 162-176. https://doi.org/10.1111/j.1099-1123.2012.00462.x 
Huang, H.-W., Raghunandan, K., \& Rama, D. (2009). Audit fees for initial audit engagements before and after SOX. Auditing: A Journal of Practice \& Theory, 28(1), 171-190. https://doi.org/10.2308/aud.2009.28.1.171

Langli, J.C., \& Svanström, T. (2014). Audits of private companies. In: D. Hay, W.R. Knechel, \& M. Willekens, eds. The Routledge Companion to Auditing. 148-158. New York: Routledge.

Mayhew, B. W. (2005). Discussion of impact of the SEC's public disclosure requirement on subsequent period fees and implications for market efficiency. Auditing: A Journal of Practice \& Theory, 25(Supplement), 161-169. https://doi.org/10.2308/aud.2005.24.s$\underline{1.161}$

Nagy, A. L. (2005). Mandatory audit firm turnover, financial reporting quality, and client bargaining power: The case of Arthur Andersen. Accounting Horizons, 19(2), 51-68. https://doi.org/10.2308/acch.2005.19.2.51

Neter, J. W., Wasserman, W., \& Kutner, M. H. (1989). Applied Linear Regression Models. Homewood, IL: Irwin.

Numan, W., \& Willekens, M. (2012a). An empirical test of spatial competition in the audit market. Journal of Accounting and Economics, 53(1-2), 450-465. https://doi.org/10.1016/j.jacceco.2011.10.002

Numan, W., \& Willekens, M. (2012b). Competitive pressure, audit quality and industry specialization. Working paper, KU Leuven.

Pearson, T., \& Trompeter, G. (1994). Competition in the market for audit services: The effect of supplier concentration on audit fees. Contemporary Accounting Research, 11(1), $115-135$. 
Petersen, M. A. (2009). Estimating standard errors in finance panel data sets: Comparing approaches. The Review of Financial Studies, 22(1), 435-480.

https://doi.org/10.1093/rfs/hhn053

Royal Decree (April 25, 2007) on changes in Company Code: Article 4 - adjustment of article $134 \S 2$ Company Code.

Security and Exchange Committee (SEC) (2000). Final Rule: Revision of the commission's auditor independence requirements. Available at: https://www.sec.gov/rules/final/337919.htm.

Simunic, D. (1980). The pricing of audit services: Theory and evidence. Journal of Accounting Research, 18(1), 161-90. DOI: 10.2307/2490397

Su, X., \& Wu, X. (2017). Public disclosure of audit fees and bargaining power between the client and auditor: Evidence from China. The International Journal of Accounting, 52(1), 64-76. https://doi.org/10.1016/j.intacc.2017.01.001

Van Caneghem, T. (2010). Audit pricing and the Big4 fee premium: Evidence from Belgium. Managerial Auditing Journal, 25(2), 122-139. https://doi.org/10.1108/02686901011008945

Vanstraelen, A., \& Schelleman, S. (2017). Auditing private companies: What do we know? Accounting and Business Research, 47(5), 565-584. https://doi.org/10.1080/00014788.2017.1314104

Verrecchia, R. E. (2001). Essays on disclosure. Journal of Accounting \& Economics, 32, 97180. https://doi.org/10.1016/S0165-4101(01)00025-8

Vuong, Q. (1989). Likelihood ratio tests for model selection and nonnested hypotheses. Econometrica, 57(2), 307-333. DOI: 10.2307/1912557

Weets, V., \& Jegers, M. (1997). Are the Big Six big in Belgium? European Accounting Review, 6(4), 773-789. https://doi.org/10.1080/09638189700000017 
Willekens, M., \& Achmadi, C. (2003). Pricing and supplier concentration in the private client segment of the audit market: Market power or concentration? International Journal of Accounting, 38(4), 431-455. https://doi.org/10.1016/j.intacc.2003.09.002

Wooldridge, J. M. (2010). Econometric analysis of cross section and panel data, second ed. London: The MITT Press. 


\begin{tabular}{|c|c|c|c|c|}
\hline & 2004 & 2007 & 2010 & Total \\
\hline $\begin{array}{l}\text { IBR }^{*} \text { audit fee and auditor data } \& \text { client financial } \\
\text { statement data available in the Bel-First database }\end{array}$ & 16,232 & 16,053 & 16,596 & 48,881 \\
\hline - Negative and null fees & -352 & -326 & -445 & $-1,123$ \\
\hline - Unavailable data to compute control variables & $-1,374$ & $-1,007$ & -907 & $-3,288$ \\
\hline - Observations without industry data & $-3,025$ & $-2,000$ & $-1,585$ & $-6,610$ \\
\hline - Financial industry observations & $\begin{array}{r}-754 \\
-29\end{array}$ & $\begin{array}{r}-905 \\
-52\end{array}$ & $\begin{array}{r}-878 \\
-48\end{array}$ & $-2,537$ \\
\hline $\begin{array}{l}\text { - Listed firms } \\
\text { Unbalanced sample }\end{array}$ & $\begin{array}{r}-29 \\
\mathbf{1 0 , 6 9 8}\end{array}$ & $\begin{array}{r}-52 \\
11,763\end{array}$ & $\begin{array}{r}-48 \\
12,733\end{array}$ & $\begin{array}{r}-129 \\
\mathbf{3 5 , 1 9 4}\end{array}$ \\
\hline Balanced sample & 6,313 & 6,313 & 6,313 & 18,939 \\
\hline
\end{tabular}

\footnotetext{
* Instituut van de Bedrijfsrevisoren (the Belgian Institute of Registered Auditors).
} 


\section{Table 2. Variable definitions}

LnFee

Year

ClientBargainingPower

CompetitivePressure

Size

InvRec

Current

Lev

Loss

YearEnd

Joint

Big4

IndustryPortfolioShare

HerfIndex

Suppliers

Industry dummies

$\varepsilon$
Natural log of inflation-adjusted audit fee in thousands of Euros

Dummy variables for financial years 2007 (Y2007) and 2010 (Y2010), with 2004 serving as the reference year

Client's total assets divided by the sum of clients' total assets for all companies in a Belgian region audited by the company's incumbent auditor

$-1 *$ (Smallest absolute market share difference (based on client audit fees) between the incumbent auditor and his closest competitor) (see Numan \& Willekens, 2012 for additional detail)

Natural log of total assets (in thousands of Euros)

Ratio of inventory plus receivables divided by total assets

Current ratio (i.e., current assets divided by current liabilities)

Ratio of total assets minus equity divided by total assets

Dummy variable equal to 1 if the client reports a loss in the current year, 0 otherwise

Dummy variable equal to 1 if the client has a December 31 st year-end, 0 otherwise

Dummy variable equal to 1 if the audit is performed jointly with another audit firm, 0 otherwise

Dummy variable equal to 1 if the incumbent auditor is a Big 4 audit firm, 0 otherwise

Fees an audit firm generates in an industry as a percentage of the total fees generated by an audit firm in a region

Herfindahl index based on audit fees in an audit market*

Number of audit firms active in an audit market*

Dummy variables based on Nace-BEL industry codes

Error term

* An audit market is defined as a Nace-BEL industry in a Belgian Region (Flemish, Brussels Capital, or Walloon Region).

Note: All continuous variables are winsorized at the top and bottom 1 percent. 
Table 3. Descriptive statistics for Equation 1 audit fee model - full balanced sample $(\mathrm{N}=\mathbf{1 8 , 9 3 9})$

\begin{tabular}{|c|c|c|c|c|c|c|c|}
\hline Variable & Mean & $\begin{array}{r}\text { Standard } \\
\text { Deviation }\end{array}$ & Minimum & $\begin{array}{r}.25\left(1^{\text {st }}\right. \\
\text { quartile })\end{array}$ & Median & $\begin{array}{c}.75(3 \mathrm{rd} \\
\text { quartile })\end{array}$ & Maximum \\
\hline Fees in $€$ & 11,669 & 15,541 & 620 & 3,442 & 6,157 & 13,043 & 93,642 \\
\hline $\begin{array}{l}\text { Fees as a } \% \text { of total } \\
\text { assets }\end{array}$ & 0.212 & 0.362 & 0.002 & 0.039 & 0.090 & 0.214 & 2.383 \\
\hline Total assets in $000 €$ & 40,348 & 13,094 & 62 & 2,767 & 7,189 & 19,675 & 974,406 \\
\hline ClientBargainingPower & 0.027 & 0.096 & 0.000 & 0.000 & 0.001 & 0.010 & 0.743 \\
\hline CompetitivePressure & -0.015 & 0.025 & -0.140 & -0.016 & -0.005 & -0.000 & 0.000 \\
\hline Size & 8.947 & 1.705 & 4.123 & 7.926 & 8.880 & 9.887 & 13.790 \\
\hline InvRec & 0.428 & 0.293 & 0.000 & 0.154 & 0.439 & 0.669 & 0.977 \\
\hline Current & 5.217 & 20.437 & 0.018 & 1.053 & 1.435 & 2.409 & 180.000 \\
\hline Lev & 0.667 & 0.494 & 0.005 & 0.413 & 0.660 & 0.835 & 4.409 \\
\hline Loss & 0.215 & 0.411 & 0.000 & 0.000 & 0.000 & 0.000 & 1.000 \\
\hline YearEnd & 0.829 & 0.377 & 0.000 & 1.000 & 1.000 & 1.000 & 1.000 \\
\hline Joint & 0.018 & 0.134 & 0.000 & 0.000 & 0.000 & 0.000 & 1.000 \\
\hline Big4 & 0.494 & 0.500 & 0.000 & 0.000 & 0.000 & 1.000 & 1.000 \\
\hline IndustryPortfolioShare & 0.263 & 0.184 & 0.007 & 0.099 & 0.265 & 0.354 & 1.000 \\
\hline HerfIndex & 0.139 & 0.038 & 0.048 & 0.121 & 0.139 & 0.165 & 0.230 \\
\hline Suppliers & 105.228 & 33.645 & 29.000 & 88.000 & 101.000 & 139.000 & 149.000 \\
\hline
\end{tabular}

Notes: Variable definitions found in Table 2. 
Table 4. Descriptive statistics for Equation 1 audit fee model - per year

\begin{tabular}{|c|c|c|c|c|c|c|c|c|c|c|c|c|c|c|c|c|}
\hline \multirow[b]{2}{*}{ Variable } & \multicolumn{7}{|c|}{$2004(N=6,313)$} & \multicolumn{7}{|c|}{$2007(\mathrm{~N}=6,313)$} & \multicolumn{2}{|c|}{ T-test } \\
\hline & Mean & $\begin{array}{r}\text { Standard } \\
\text { Deviation }\end{array}$ & Min & $\begin{array}{r}.25\left(1^{\text {st }}\right. \\
\text { Quartile })\end{array}$ & Median & $\begin{array}{r}.75\left(3^{\text {rd }}\right. \\
\text { Quartile })\end{array}$ & Max & Mean & $\begin{array}{r}\text { Standard } \\
\text { Deviation }\end{array}$ & Min & $\begin{array}{r}.25\left(1^{\text {st }}\right. \\
\text { Quartile }\end{array}$ & Median & $\begin{array}{r}.75\left(3^{\text {rd }}\right. \\
\text { Quartile) }\end{array}$ & $\operatorname{Max}$ & & \\
\hline Audit fees in $€$ & 10,768 & 14,462 & 620 & 3,160 & 5,791 & 12,000 & 93,642 & 11,823 & 15,768 & 620 & 3,457 & 6,227 & 13,367 & 93,642 & -6.976 & $* * *$ \\
\hline Total assets in $000 €$ & 34,783 & 120,327 & 62 & 2,514 & 6,267 & 16,555 & 974,406 & 41,591 & 13,232 & 62 & 2,991 & 7,579 & 20,524 & 974,406 & -3.025 & $* * *$ \\
\hline ClientBargainingPower & 0.029 & 0.099 & 0.000 & 0.000 & 0.001 & 0.011 & 0.743 & 0.027 & 0.095 & 0.000 & 0.000 & 0.001 & 0.010 & 0.743 & 1.086 & \\
\hline CompetitivePressure & -0.013 & 0.021 & -0.140 & -0.014 & -0.006 & -0.000 & 0.000 & -0.011 & 0.019 & -0.140 & -0.011 & -0.004 & -0.000 & 0.000 & -6.009 & $* * *$ \\
\hline Size & 8.816 & 1.657 & 4.123 & 7.830 & 8.743 & 9.714 & 13.790 & 9.008 & 1.691 & 4.123 & 8.003 & 8.933 & 9.929 & 13.790 & -6.457 & $* * *$ \\
\hline InvRec & 0.445 & 0.290 & 0.000 & 0.184 & 0.465 & 0.679 & 0.977 & 0.437 & 0.294 & 0.000 & 0.165 & 0.451 & 0.679 & 0.977 & 1.471 & \\
\hline Current & 3.819 & 15.892 & 0.018 & 1.014 & 1.330 & 2.084 & 180.000 & 5.204 & 20.053 & 0.018 & 1.073 & 1.455 & 2.419 & 180.000 & -4.301 & $* * *$ \\
\hline Lev & 0.704 & 0.469 & 0.005 & 0.480 & 0.704 & 0.863 & 4.409 & 0.661 & 0.482 & 0.005 & 0.412 & 0.655 & 0.828 & 4.409 & 5.024 & $* * *$ \\
\hline Loss & 0.223 & 0.417 & 0.000 & 0.000 & 0.000 & 0.000 & 1.000 & 0.183 & 0.387 & 0.000 & 0.000 & 0.000 & 0.000 & 1.000 & 5.601 & $* * *$ \\
\hline YearEnd & 0.825 & 0.380 & 0.000 & 1.000 & 1.000 & 1.000 & 1.000 & 0.827 & 0.378 & 0.000 & 1.000 & 1.000 & 1.000 & 1.000 & -0.352 & \\
\hline Joint & 0.017 & 0.130 & 0.000 & 0.000 & 0.000 & 0.000 & 1.000 & 0.026 & 0.158 & 0.000 & 0.000 & 0.000 & 0.000 & 1.000 & -3.268 & $* * *$ \\
\hline Big4 & 0.527 & 0.499 & 0.000 & 0.000 & 1.000 & 1.000 & 1.000 & 0.484 & 0.500 & 0.000 & 0.000 & 0.000 & 1.000 & 1.000 & 4.882 & $* * *$ \\
\hline IndustryPortfolioShare & 0.250 & 0.181 & 0.007 & 0.090 & 0.255 & 0.334 & 1.000 & 0.269 & 0.187 & 0.007 & 0.099 & 0.271 & 0.378 & 1.000 & -5.926 & $* * *$ \\
\hline HerfIndex & 0.125 & 0.035 & 0.048 & 0.115 & 0.122 & 0.133 & 0.230 & 0.143 & 0.036 & 0.048 & 0.135 & 0.145 & 0.165 & 0.230 & -28.052 & $* * *$ \\
\hline Suppliers & 107.466 & 35.263 & 34.000 & 88.000 & 103.000 & 149.000 & 149.000 & 107.040 & 35.367 & 34.000 & 88.000 & 101.000 & 148.000 & 148.000 & 0.679 & \\
\hline
\end{tabular}


Table 4, continued

\begin{tabular}{|c|c|c|c|c|c|c|c|c|c|}
\hline \multirow[b]{2}{*}{ Variable } & \multicolumn{7}{|c|}{$2010(N=6,313)$} & \multicolumn{2}{|c|}{ T-test } \\
\hline & Mean & $\begin{array}{c}\text { Standard } \\
\text { Deviation }\end{array}$ & Min & $\begin{array}{c}.25\left(1^{\text {st }}\right. \\
\text { Quartile }) \\
\end{array}$ & Median & $\begin{array}{c}.75\left(3^{\text {rd }}\right. \\
\text { Quartile }) \\
\end{array}$ & Max & & \\
\hline Audit fees in $€$ & 12,415 & 16,295 & 620 & 3,606 & 6,522 & 13,990 & 93,642 & -11.327 & $* * *$ \\
\hline Total assets in $000 €$ & 44,670 & 139,300 & 62 & 2,833 & 7,860 & 21,893 & 974,406 & -4.268 & $* * *$ \\
\hline ClientBargainingPower & 0.025 & 0.093 & 0.000 & 0.000 & 0.001 & 0.008 & 0.743 & 2.130 & $* *$ \\
\hline CompetitivePressure & -0.022 & 0.032 & -0.140 & -0.043 & -0.005 & -0.000 & 0.000 & 19.521 & $* * *$ \\
\hline Size & 9.016 & 1.759 & 4.123 & 7.949 & 8.970 & 9.994 & 13.790 & -6.595 & $* * *$ \\
\hline InvRec & 0.401 & 0.294 & 0.000 & 0.119 & 0.394 & 0.643 & 0.977 & 8.451 & $* * *$ \\
\hline Current & 6.628 & 24.382 & 0.018 & 1.092 & 1.541 & 2.820 & 180.000 & -7.669 & $* * *$ \\
\hline Lev & 0.638 & 0.527 & 0.005 & 0.359 & 0.620 & 0.809 & 4.409 & 7.422 & $* * *$ \\
\hline Loss & 0.239 & 0.426 & 0.000 & 0.000 & 0.000 & 0.000 & 1.000 & -2.069 & $* * *$ \\
\hline YearEnd & 0.833 & 0.373 & 0.000 & 1.000 & 1.000 & 1.000 & 1.000 & -1.229 & \\
\hline Joint & 0.012 & 0.108 & 0.000 & 0.000 & 0.000 & 0.000 & 1.000 & 2.458 & $* * *$ \\
\hline Big4 & 0.469 & 0.499 & 0.000 & 0.000 & 0.000 & 1.000 & 1.000 & 6.543 & $* * *$ \\
\hline IndustryPortfolioShare & 0.270 & 0.185 & 0.007 & 0.108 & 0.282 & 0.365 & 1.000 & -6.197 & $* * *$ \\
\hline HerfIndex & 0.148 & 0.040 & 0.048 & 0.139 & 0.142 & 0.182 & 0.221 & -33.360 & $* * *$ \\
\hline Suppliers & 101.178 & 29.618 & 29.000 & 88.000 & 101.000 & 137.000 & 137.000 & 10.850 & $* * *$ \\
\hline
\end{tabular}

Notes: Variable definitions found in Table 2. T-test reports results for a t-test for a difference in means (always compared to the mean of 2004). $* * *$ denotes statistical significance at the $1 \%$ level,

** denotes statistical significance at the $5 \%$ level, and * denotes statistical significance at the $10 \%$ level. 
Table 5. Pearson correlations regression variables for Equation 1 audit fee model - full balanced sample $(\mathrm{N}=18,939)$

\begin{tabular}{|c|c|c|c|c|c|c|c|c|c|c|c|c|c|}
\hline & LnFees & Y2004 & Y2007 & Y2010 & $\begin{array}{c}\text { Client } \\
\text { Bargaining } \\
\text { Power }\end{array}$ & $\begin{array}{l}\text { Competitive } \\
\text { Pressure }\end{array}$ & Size & InvRec & Current & Lev & Loss & YearEnd & Joint \\
\hline LnFees & 1.0000 & & & & & & & & & & & & \\
\hline \multirow[t]{2}{*}{ Y2004 } & -0.0489 & 1.0000 & & & & & & & & & & & \\
\hline & 0.0000 & & & & & & & & & & & & \\
\hline \multirow[t]{2}{*}{ Y2007 } & 0.0059 & -0.5000 & 1.0000 & & & & & & & & & & \\
\hline & 0.4163 & 0.0000 & & & & & & & & & & & \\
\hline \multirow[t]{2}{*}{ Y2010 } & 0.0430 & -0.5000 & -0.5000 & 1.0000 & & & & & & & & & \\
\hline & 0.0000 & 0.0000 & 0.0000 & & & & & & & & & & \\
\hline \multirow[t]{2}{*}{ ClientBargainingPower } & -0.0274 & 0.0136 & -0.0003 & -0.0133 & 1.0000 & & & & & & & & \\
\hline & 0.0002 & 0.0614 & 0.9724 & 0.0663 & & & & & & & & & \\
\hline \multirow[t]{2}{*}{ CompetitivePressure } & -0.2511 & 0.0678 & 0.1277 & -0.1955 & 0.1428 & 1.0000 & & & & & & & \\
\hline & 0.0000 & 0.0000 & 0.0000 & 0.0000 & 0.0000 & & & & & & & & \\
\hline \multirow[t]{2}{*}{ Size } & 0.5558 & -0.0543 & 0.0255 & 0.0289 & 0.1411 & -0.0984 & 1.0000 & & & & & & \\
\hline & 0.0000 & 0.0000 & 0.0005 & 0.0001 & 0.0000 & 0.0000 & & & & & & & \\
\hline \multirow[t]{2}{*}{ InvRec } & 0.0742 & 0.0415 & 0.0230 & -0.0645 & -0.0356 & 0.0618 & -0.1186 & 1.0000 & & & & & \\
\hline & 0.0000 & 0.0000 & 0.0015 & 0.0000 & 0.0000 & 0.0000 & 0.0000 & & & & & & \\
\hline \multirow[t]{2}{*}{ Current } & -0.1268 & -0.0484 & -0.0005 & 0.0488 & -0.0116 & -0.0353 & -0.0171 & -0.2110 & 1.0000 & & & & \\
\hline & 0.0000 & 0.0000 & 0.9505 & 0.0000 & 0.1096 & 0.0000 & 0.0186 & 0.0000 & & & & & \\
\hline \multirow[t]{2}{*}{ Lev } & 0.0229 & 0.0517 & -0.0091 & -0.0426 & -0.0141 & -0.0054 & -0.1561 & 0.1698 & -0.2066 & 1.0000 & & & \\
\hline & 0.0017 & 0.0000 & 0.2085 & 0.0000 & 0.0529 & 0.4614 & 0.0000 & 0.0000 & 0.0000 & & & & \\
\hline \multirow[t]{2}{*}{ Loss } & -0.0262 & 0.0141 & -0.0549 & 0.0408 & -0.0192 & -0.0130 & -0.1138 & -0.0487 & 0.0064 & 0.2564 & 1.0000 & & \\
\hline & 0.0003 & 0.0526 & 0.0000 & 0.0000 & 0.0081 & 0.0726 & 0.0000 & 0.0000 & 0.3756 & 0.0000 & & & \\
\hline \multirow[t]{2}{*}{ YearEnd } & -0.0340 & -0.0066 & -0.0022 & 0.0088 & 0.0254 & 0.0014 & -0.0074 & 0.0030 & -0.0075 & 0.0232 & 0.0085 & 1.0000 & \\
\hline & 0.0000 & 0.3611 & 0.7643 & 0.2251 & 0.0005 & 0.8479 & 0.3056 & 0.6826 & 0.3039 & 0.0014 & 0.2437 & & \\
\hline \multirow[t]{2}{*}{ Joint } & 0.0299 & -0.0056 & 0.0389 & -0.0333 & 0.0494 & 0.0216 & 0.0718 & -0.0234 & -0.0013 & 0.0037 & 0.0048 & 0.0031 & 1.0000 \\
\hline & 0.0000 & 0.4416 & 0.0000 & 0.0000 & 0.0000 & 0.0030 & 0.0000 & 0.0013 & 0.8584 & 0.6081 & 0.5094 & 0.6655 & \\
\hline
\end{tabular}




\begin{tabular}{|c|c|c|c|c|c|c|c|c|c|c|c|c|c|c|c|c|c|}
\hline & LnFees & Y2004 & Y2007 & Y2010 & $\begin{array}{c}\text { Client } \\
\text { Bargaining } \\
\text { Power }\end{array}$ & $\begin{array}{l}\text { Competitive } \\
\text { Pressure }\end{array}$ & Size & InvRec & Current & Lev & Loss & YearEnd & Joint & Big4 & $\begin{array}{c}\text { Industry } \\
\text { Portfolio } \\
\text { Share }\end{array}$ & $\begin{array}{l}\text { Herf } \\
\text { Index }\end{array}$ & Suppliers \\
\hline \multirow[t]{2}{*}{ Big4 } & 0.3996 & 0.0479 & -0.0135 & -0.0344 & -0.2611 & -0.5176 & 0.1299 & -0.0776 & 0.0501 & 0.0333 & 0.0196 & -0.0075 & -0.0030 & 1.0000 & & & \\
\hline & 0.0000 & 0.0000 & 0.0629 & 0.0000 & 0.0000 & 0.0000 & 0.0000 & 0.0000 & 0.0000 & 0.0000 & 0.0069 & 0.3039 & 0.6783 & & & & \\
\hline \multirow[t]{2}{*}{ IndustryPortfolioShare } & 0.0687 & -0.0506 & 0.0238 & 0.0267 & 0.3807 & 0.0990 & 0.0395 & 0.2518 & -0.0719 & -0.0067 & -0.0485 & -0.0332 & -0.0053 & -0.2188 & 1.0000 & & \\
\hline & 0.0000 & 0.0000 & 0.0010 & 0.0002 & 0.0000 & 0.0000 & 0.0000 & 0.0000 & 0.0000 & 0.3578 & 0.0000 & 0.0000 & 0.4679 & 0.0000 & & & \\
\hline \multirow[t]{2}{*}{ HerfIndex } & 0.1438 & -0.2462 & 0.0813 & 0.1649 & -0.0550 & -0.1939 & 0.0478 & -0.0358 & 0.0202 & 0.0053 & 0.0348 & -0.0259 & -0.0033 & 0.1413 & 0.0295 & 1.0000 & \\
\hline & 0.0000 & 0.0000 & 0.0000 & 0.0000 & 0.0000 & 0.0000 & 0.0000 & 0.0000 & 0.0053 & 0.4679 & 0.0000 & 0.0004 & 0.6509 & 0.0000 & 0.0000 & & \\
\hline \multirow[t]{2}{*}{ Suppliers } & 0.0777 & 0.0470 & 0.0381 & -0.0851 & -0.0804 & 0.0724 & -0.0102 & 0.3024 & -0.0863 & -0.0366 & -0.0824 & -0.0817 & -0.0478 & -0.0349 & 0.4951 & -0.0876 & 1.0000 \\
\hline & 0.0000 & 0.0000 & 0.0000 & 0.0000 & 0.0000 & 0.0000 & 0.1602 & 0.0000 & 0.0000 & 0.0000 & 0.0000 & 0.0000 & 0.0000 & 0.0000 & 0.0000 & 0.0000 & \\
\hline
\end{tabular}

Notes: The level of significance is presented in italic. All variable definitions found in Table 2. 
Table 6. Audit fee regression analyses - main model (Equation 1) with dependent variable LnFees

\begin{tabular}{|c|c|c|c|c|c|c|c|c|c|c|c|c|}
\hline \multirow[b]{2}{*}{ Parameter } & \multicolumn{3}{|c|}{ Full balanced sample } & \multicolumn{3}{|c|}{2004} & \multicolumn{3}{|c|}{2007} & \multicolumn{3}{|c|}{2010} \\
\hline & Estimate & T-stat & P-value & Estimate & T-stat & P-value & Estimate & T-stat & P-value & Estimate & T-stat & P-value \\
\hline Intercept & -1.5210 & -21.39 & 0.000 & -1.4401 & -15.25 & 0.000 & -1.5156 & -17.48 & 0.000 & -1.4107 & -16.52 & 0.000 \\
\hline Y2007 & 0.0501 & 5.31 & 0.000 & & & & & & & & & \\
\hline Y2010 & 0.1076 & 9.82 & 0.000 & & & & & & & & & \\
\hline ClientBargainingPower & -0.2637 & -3.24 & 0.001 & -0.1923 & -1.82 & 0.069 & -0.2910 & -2.96 & 0.003 & -0.3304 & -3.43 & 0.001 \\
\hline CompetitivePressure & -0.8216 & -3.00 & 0.003 & 0.2472 & 0.42 & 0.672 & 0.4742 & 0.81 & 0.419 & -1.9940 & -4.55 & 0.000 \\
\hline Size & 0.3174 & 60.88 & 0.000 & 0.3115 & 45.89 & 0.000 & 0.3199 & 51.50 & 0.000 & 0.3192 & 53.49 & 0.000 \\
\hline InvRec & 0.3074 & 10.12 & 0.000 & 0.2822 & 7.06 & 0.000 & 0.3562 & 9.59 & 0.000 & 0.2969 & 8.33 & 0.000 \\
\hline Current & -0.0045 & -11.66 & 0.000 & -0.0042 & -6.38 & 0.000 & -0.0046 & -8.10 & 0.000 & -0.0046 & -10.38 & 0.000 \\
\hline Lev & 0.1096 & 7.35 & 0.000 & 0.0967 & 4.39 & 0.000 & 0.0990 & 4.82 & 0.000 & 0.1287 & 6.64 & 0.000 \\
\hline Loss & 0.0600 & 3.80 & 0.000 & 0.0472 & 1.97 & 0.049 & 0.0538 & 2.07 & 0.039 & 0.0794 & 3.51 & 0.000 \\
\hline YearEnd & -0.0571 & -2.78 & 0.005 & -0.0393 & -1.55 & 0.122 & -0.0592 & -2.42 & 0.016 & -0.0699 & -3.00 & 0.003 \\
\hline Joint & -0.0243 & -0.53 & 0.598 & 0.0732 & 0.95 & 0.344 & -0.0614 & -0.96 & 0.335 & -0.1327 & -1.89 & 0.059 \\
\hline Big4 & 0.6600 & 37.14 & 0.000 & 0.5999 & 26.17 & 0.000 & 0.7353 & 34.35 & 0.000 & 0.6400 & 23.52 & 0.000 \\
\hline IndustryPortfolioShare & 0.2646 & 4.54 & 0.000 & 0.2560 & 3.41 & 0.001 & 0.2879 & 4.14 & 0.000 & 0.2276 & 3.23 & 0.001 \\
\hline HerfIndex & 0.4074 & 1.55 & 0.121 & 0.3172 & 0.74 & 0.461 & 0.5252 & 1.72 & 0.086 & 0.4539 & 1.40 & 0.161 \\
\hline Suppliers & -0.0012 & -3.57 & 0.000 & -0.0011 & -2.93 & 0.003 & -0.0012 & -3.31 & 0.001 & -0.0015 & -3.44 & 0.001 \\
\hline Adj. R2 & & 0.4896 & & & 0.4323 & & & 0.5077 & & & 0.5288 & \\
\hline Industry dummies & & Yes & & & Yes & & & Yes & & & Yes & \\
\hline $\mathrm{N}$ & & 18,939 & & & 6,313 & & & 6,313 & & & 6,313 & \\
\hline
\end{tabular}

Notes: Standard errors are adjusted for heteroscedasticity and clustered on client firm. Variable definitions found in Table 2. 
Table 7. Audit fee regression analyses - disclosure effect (Equation 1) with dependent variable LnFees

\begin{tabular}{|c|c|c|c|c|c|c|c|c|c|c|c|c|c|c|c|c|c|c|}
\hline \multirow[b]{3}{*}{ Parameter } & \multicolumn{6}{|c|}{ Full balanced sample } & \multicolumn{6}{|c|}{ Positive abnormal audit fees } & \multicolumn{6}{|c|}{ Negative abnormal audit fees } \\
\hline & \multicolumn{3}{|c|}{$2004 / 2007$} & \multicolumn{3}{|c|}{$2007 / 2010$} & \multicolumn{3}{|c|}{$2004 / 2007$} & \multicolumn{3}{|c|}{$2007 / 2010$} & \multicolumn{3}{|c|}{$2004 / 2007$} & \multicolumn{3}{|c|}{$2007 / 2010$} \\
\hline & Estimate & T-stat & P-value & Estimate & T-stat & P-value & Estimate & T-stat & P-value & Estimate & T-stat & P-value & Estimate & T-stat & P-value & Estimate & T-stat & P-value \\
\hline Intercept & -1.5022 & -19.47 & 0.000 & -1.4995 & -19.45 & 0.000 & -1.1134 & -15.38 & 0.000 & -1.1245 & -16.07 & 0.000 & -1.6774 & -21.53 & 0.000 & -1.7417 & -22.52 & 0.000 \\
\hline Y2007 & 0.0458 & 4.69 & 0.000 & & & & -0.1485 & -14.30 & 0.000 & & & & 0.2487 & 18.55 & 0.000 & & & \\
\hline Y2010 & & & & 0.0555 & 6.92 & 0.000 & & & & -0.0753 & -8.32 & 0.000 & & & & 0.2173 & 19.90 & 0.000 \\
\hline ClientBargainingPower & -0.2343 & -2.58 & 0.010 & -0.3121 & -3.67 & 0.000 & -0.3705 & -4.22 & 0.000 & -0.4559 & -5.48 & 0.000 & -0.0002 & -0.00 & 0.997 & -0.0317 & -0.40 & 0.689 \\
\hline CompetitivePressure & 0.5120 & 1.14 & 0.256 & -0.9796 & -3.21 & 0.001 & 0.1846 & 0.46 & 0.647 & -0.0559 & -0.19 & 0.850 & 0.7187 & 1.41 & 0.160 & -0.7871 & -1.97 & 0.049 \\
\hline Size & 0.3159 & 55.82 & 0.000 & 0.3198 & 58.21 & 0.000 & 0.3359 & 66.72 & 0.000 & 0.3317 & 70.79 & 0.000 & 0.2823 & 47.77 & 0.000 & 0.2902 & 50.17 & 0.000 \\
\hline InvRec & 0.3187 & 9.48 & 0.000 & 0.3235 & 10.08 & 0.000 & 0.2694 & 8.78 & 0.000 & 0.2950 & 10.16 & 0.000 & 0.3328 & 10.21 & 0.000 & 0.3891 & 12.58 & 0.000 \\
\hline Current & -0.0045 & -9.00 & 0.000 & -0.0046 & -11.32 & 0.000 & -0.0041 & -6.93 & 0.000 & -0.0041 & -9.45 & 0.000 & -0.0036 & -7.49 & 0.000 & -0.0041 & -10.37 & 0.000 \\
\hline Lev & 0.0971 & 5.57 & 0.000 & 0.1156 & 6.92 & 0.000 & 0.0872 & 4.90 & 0.000 & 0.1148 & 7.88 & 0.000 & 0.1004 & 5.58 & 0.000 & 0.0833 & 4.71 & 0.000 \\
\hline Loss & 0.0514 & 2.72 & 0.007 & 0.0671 & 3.62 & 0.000 & 0.0667 & 3.81 & 0.000 & 0.0937 & 5.78 & 0.000 & 0.0276 & 1.36 & 0.174 & 0.0116 & 0.57 & 0.567 \\
\hline YearEnd & -0.0498 & -2.25 & 0.025 & -0.0659 & -3.06 & 0.002 & -0.0829 & -4.18 & 0.000 & -0.1082 & -5.78 & 0.000 & -0.0226 & -1.04 & 0.299 & -0.0467 & -2.30 & 0.022 \\
\hline Joint & 0.0062 & 0.12 & 0.906 & -0.0823 & -1.60 & 0.110 & 0.0506 & 0.95 & 0.342 & -0.0733 & -1.55 & 0.121 & 0.0075 & 0.13 & 0.899 & -0.0218 & -0.41 & 0.682 \\
\hline Big4 & 0.6694 & 35.21 & 0.000 & 0.6984 & 35.42 & 0.000 & 0.6931 & 39.79 & 0.000 & 0.7288 & 41.01 & 0.000 & 0.5171 & 25.16 & 0.000 & 0.5858 & 28.45 & 0.000 \\
\hline IndustryPortfolioShare & 0.2739 & 4.27 & 0.000 & 0.2659 & 4.38 & 0.000 & 0.4098 & 7.17 & 0.000 & 0.3350 & 6.25 & 0.000 & 0.1333 & 2.12 & 0.034 & 0.1365 & 2.38 & 0.017 \\
\hline HerfIndex & 0.4549 & 1.52 & 0.129 & 0.4336 & 1.63 & 0.102 & 0.5130 & 1.84 & 0.065 & 0.7397 & 3.17 & 0.002 & 0.0203 & 0.06 & 0.949 & -0.1270 & -0.46 & 0.646 \\
\hline Suppliers & -0.0012 & -3.58 & 0.000 & -0.0012 & -3.41 & 0.001 & -0.0011 & -3.76 & 0.000 & -0.0009 & -2.98 & 0.003 & -0.0012 & -3.33 & 0.001 & -0.0006 & -1.66 & 0.096 \\
\hline Adj. R2 & & 0.4699 & & & 0.5176 & & & 0.7072 & & & 0.7489 & & & 0.5035 & & & 0.5597 & \\
\hline Industry fixed effects & & Yes & & & Yes & & & Yes & & & Yes & & & Yes & & & Yes & \\
\hline $\mathrm{N}$ & & 12,626 & & & 12,626 & & & 6,522 & & & 6,522 & & & 6,104 & & & 6,104 & \\
\hline
\end{tabular}

Notes: Standard errors are adjusted for heteroscedasticity and clustered on client firm. Variable definitions found in Table 2. 
Table 8. Audit fee regression analysis - client bargaining power (Equation 2) with dependent variable LnFees

\begin{tabular}{|c|c|c|c|c|c|c|c|c|c|c|c|c|c|c|c|c|c|c|}
\hline \multirow[b]{3}{*}{ Parameter } & \multicolumn{6}{|c|}{ Full balanced sample } & \multicolumn{6}{|c|}{ Positive abnormal audit fees } & \multicolumn{6}{|c|}{ Negative abnormal audit fees } \\
\hline & \multicolumn{3}{|c|}{$2004 / 2007$} & \multicolumn{3}{|c|}{$2007 / 2010$} & \multicolumn{3}{|c|}{$2004 / 2007$} & \multicolumn{3}{|c|}{$2007 / 2010$} & \multicolumn{3}{|c|}{$2004 / 2007$} & \multicolumn{3}{|c|}{$2007 / 2010$} \\
\hline & Estimate & T-stat & P-value & Estimate & T-stat & $\mathrm{P}$-value & Estimate & T-stat & P-value & Estimate & T-stat & P-value & Estimate & T-stat & P-value & Estimate & T-stat & P-value \\
\hline Intercept & -1.5059 & -19.52 & 0.000 & -1.5001 & -19.45 & 0.000 & -1.1161 & -15.40 & 0.000 & -1.1244 & -16.07 & 0.000 & -1.6818 & -21.58 & 0.000 & -1.7456 & -22.59 & 0.000 \\
\hline Y2007 & 0.0529 & 5.18 & 0.000 & & & & -0.1446 & -13.34 & 0.000 & & & & 0.2602 & 18.41 & 0.000 & & & \\
\hline Y2010 & & & & 0.0567 & 6.59 & 0.000 & & & & -0.0754 & -7.83 & 0.000 & & & & 0.2240 & 19.29 & 0.000 \\
\hline ClientBargainingPower & -0.1158 & -1.15 & 0.250 & -0.2907 & -3.09 & 0.002 & -0.2992 & -3.38 & 0.001 & -0.4586 & -5.03 & 0.000 & 0.1760 & 1.89 & 0.059 & 0.0819 & 1.05 & 0.295 \\
\hline CompetitivePressure & 0.5032 & 1.12 & 0.264 & -0.9730 & -3.17 & 0.002 & 0.1794 & 0.44 & 0.657 & -0.0568 & -0.19 & 0.848 & 0.7056 & 1.38 & 0.167 & -0.7520 & -1.88 & 0.060 \\
\hline ClientBargainingPower*2007 & -0.2498 & -3.35 & 0.001 & & & & -0.1490 & -1.77 & 0.077 & & & & -0.3749 & -3.79 & 0.000 & & & \\
\hline ClientBargainingPower*2010 & & & & -0.0431 & -0.58 & 0.559 & & & & 0.0054 & 0.07 & 0.946 & & & & -0.2286 & -2.72 & 0.007 \\
\hline Size & 0.3160 & 55.82 & 0.000 & 0.3198 & 58.21 & 0.000 & 0.3360 & 66.73 & 0.000 & 0.3317 & 70.79 & 0.000 & 0.2822 & 47.74 & 0.000 & 0.2903 & 50.19 & 0.000 \\
\hline InvRec & 0.3189 & 9.48 & 0.000 & 0.3235 & 10.08 & 0.000 & 0.2695 & 8.79 & 0.000 & 0.2950 & 10.15 & 0.000 & 0.3331 & 10.22 & 0.000 & 0.3893 & 12.59 & 0.000 \\
\hline Current & -0.0045 & -8.99 & 0.000 & -0.0046 & -11.33 & 0.000 & -0.0041 & -6.91 & 0.000 & -0.0041 & -9.45 & 0.000 & -0.0036 & -7.50 & 0.000 & -0.0041 & -10.37 & 0.000 \\
\hline Lev & 0.0973 & 5.58 & 0.000 & 0.1156 & 6.92 & 0.000 & 0.0873 & 4.90 & 0.000 & 0.1148 & 7.88 & 0.000 & 0.1007 & 5.61 & 0.000 & 0.0832 & 4.71 & 0.000 \\
\hline Loss & 0.0511 & 2.70 & 0.007 & 0.0671 & 3.62 & 0.000 & 0.0666 & 3.81 & 0.000 & 0.0937 & 5.78 & 0.000 & 0.0270 & 1.33 & 0.184 & 0.0119 & 0.59 & 0.558 \\
\hline YearEnd & -0.0495 & -2.23 & 0.026 & -0.0659 & -3.06 & 0.002 & -0.0827 & -4.17 & 0.000 & -0.1082 & -5.78 & 0.000 & -0.0221 & -1.01 & 0.310 & -0.0469 & -2.31 & 0.021 \\
\hline Joint & 0.0027 & 0.05 & 0.958 & -0.0821 & -1.60 & 0.111 & 0.0488 & 0.92 & 0.360 & -0.0733 & -1.55 & 0.121 & 0.0018 & 0.03 & 0.975 & -0.0212 & -0.40 & 0.691 \\
\hline Big4 & 0.6695 & 35.22 & 0.000 & 0.6986 & 35.39 & 0.000 & 0.6931 & 39.79 & 0.000 & 0.7287 & 40.90 & 0.000 & 0.5177 & 25.18 & 0.000 & 0.5872 & 28.48 & 0.000 \\
\hline IndustryPortfolioShare & 0.2757 & 4.30 & 0.000 & 0.2657 & 4.37 & 0.000 & 0.4103 & 7.19 & 0.000 & 0.3350 & 6.25 & 0.000 & 0.1375 & 2.18 & 0.029 & 0.1345 & 2.35 & 0.019 \\
\hline HerfIndex & 0.4521 & 1.51 & 0.131 & 0.4329 & 1.63 & 0.103 & 0.5138 & 1.85 & 0.065 & 0.7399 & 3.17 & 0.002 & 0.0097 & 0.03 & 0.976 & -0.1288 & -0.47 & 0.642 \\
\hline Suppliers & -0.0012 & -3.59 & 0.000 & -0.0012 & -3.41 & 0.001 & -0.0011 & -3.77 & 0.000 & -0.0009 & -2.98 & 0.003 & -0.0012 & -3.36 & 0.001 & -0.0006 & -1.65 & 0.098 \\
\hline Adj. R2 & & 0.4701 & & & 0.5176 & & & 0.7072 & & & 0.7489 & & & 0.5040 & & & 0.5599 & \\
\hline Industry dummies & & Yes & & & Yes & & & Yes & & & Yes & & & Yes & & & Yes & \\
\hline $\mathrm{N}$ & & 12,626 & & & 12,626 & & & 6,522 & & & 6,522 & & & 6,104 & & & 6,104 & \\
\hline
\end{tabular}

Notes: Standard errors are adjusted for heteroscedasticity and clustered on client firm. Variable definitions found in Table 2. 
Table 9. Audit fee regression analyses - competitive pressure (Equation 3) with dependent variable LnFees

\begin{tabular}{|c|c|c|c|c|c|c|c|c|c|c|c|c|c|c|c|c|c|c|}
\hline \multirow[b]{3}{*}{ Parameter } & \multicolumn{6}{|c|}{ Full balanced sample } & \multicolumn{6}{|c|}{ Positive abnormal audit fees } & \multicolumn{6}{|c|}{ Negative abnormal audit fees } \\
\hline & \multicolumn{3}{|c|}{$2004 / 2007$} & \multicolumn{3}{|c|}{$2007 / 2010$} & \multicolumn{3}{|c|}{$2004 / 2007$} & \multicolumn{3}{|c|}{$2007 / 2010$} & \multicolumn{3}{|c|}{$2004 / 2007$} & \multicolumn{3}{|c|}{$2007 / 2010$} \\
\hline & Estimate & T-stat & P-value & Estimate & T-stat & P-value & Estimate & T-stat & P-value & Estimate & T-stat & P-value & Estimate & T-stat & P-value & Estimate & T-stat & $\mathrm{P}$-value \\
\hline Intercept & -1.4900 & & -19.33 & -1.4840 & -19.24 & 0.000 & -1.1165 & -15.44 & 0.000 & -1.1358 & -16.22 & 0.000 & -1.6528 & -21.17 & 0.000 & -1.7251 & -22.31 & 0.000 \\
\hline Y2007 & 0.0282 & 2.52 & 0.012 & & & & -0.1439 & -12.36 & 0.000 & & & & 0.2141 & 14.93 & 0.000 & & & \\
\hline Y2010 & & & & 0.0352 & 3.43 & 0.001 & & & & -0.0617 & -5.49 & 0.000 & & & & 0.1922 & 15.23 & 0.000 \\
\hline ClientBargainingPower & -0.2359 & -2.60 & 0.009 & -0.3130 & -3.68 & 0.000 & -0.3698 & -4.21 & 0.000 & -0.4562 & -5.49 & 0.000 & 0.0000 & 0.00 & 1.000 & -0.0352 & -0.44 & 0.657 \\
\hline CompetitivePressure & 1.2480 & 2.35 & 0.019 & 0.1145 & 0.21 & 0.833 & -0.0017 & -0.00 & 0.996 & -0.7592 & -1.82 & 0.069 & 2.2077 & 3.86 & 0.000 & 0.5973 & 1.10 & 0.271 \\
\hline CompetitivePressure*2007 & -1.5603 & -2.59 & 0.010 & & & & 0.3854 & 0.62 & 0.535 & & & & -3.2378 & -4.27 & 0.000 & & & \\
\hline CompetitivePressure*2010 & & & & -1.4749 & -2.60 & 0.009 & & & & 0.9350 & 1.98 & 0.047 & & & & -1.9224 & -3.16 & 0.002 \\
\hline Size & 0.3158 & 55.77 & 0.000 & 0.3196 & 58.20 & 0.000 & 0.3359 & 66.75 & 0.000 & 0.3317 & 70.90 & 0.000 & 0.2820 & 47.57 & 0.000 & 0.2900 & 50.11 & 0.000 \\
\hline InvRec & 0.3190 & 9.49 & 0.000 & 0.3249 & 10.12 & 0.000 & 0.2695 & 8.78 & 0.000 & 0.2939 & 10.12 & 0.000 & 0.3341 & 10.26 & 0.000 & 0.3904 & 12.61 & 0.000 \\
\hline Current & -0.0045 & -8.99 & 0.000 & -0.0046 & -11.39 & 0.000 & -0.0041 & -6.94 & 0.000 & -0.0041 & -9.43 & 0.000 & -0.0036 & -7.44 & 0.000 & -0.0041 & -10.42 & 0.000 \\
\hline Lev & 0.0972 & 5.57 & 0.000 & 0.1152 & 6.90 & 0.000 & 0.0873 & 4.91 & 0.000 & 0.1149 & 7.88 & 0.000 & 0.1013 & 5.61 & 0.000 & 0.0825 & 4.65 & 0.000 \\
\hline Loss & 0.0509 & 2.69 & 0.007 & 0.0679 & 3.66 & 0.000 & 0.0668 & 3.82 & 0.000 & 0.0930 & 5.74 & 0.000 & 0.0269 & 1.33 & 0.185 & 0.0124 & 0.61 & 0.539 \\
\hline YearEnd & -0.0495 & -2.23 & 0.026 & -0.0658 & -3.05 & 0.002 & -0.0832 & -4.20 & 0.000 & -0.1077 & -5.75 & 0.000 & -0.0236 & -1.08 & 0.280 & -0.0457 & -2.25 & 0.025 \\
\hline Joint & 0.0030 & 0.06 & 0.953 & -0.0793 & -1.54 & 0.123 & 0.0513 & 0.96 & 0.337 & -0.0751 & -1.58 & 0.114 & 0.0001 & 0.00 & 0.998 & -0.0179 & -0.34 & 0.736 \\
\hline Big4 & 0.6705 & 35.26 & 0.000 & 0.6988 & 35.40 & 0.000 & 0.6928 & 39.90 & 0.000 & 0.7285 & 40.95 & 0.000 & 0.5190 & 25.16 & 0.000 & 0.5862 & 28.45 & 0.000 \\
\hline IndustryPortfolioShare & 0.2757 & 4.30 & 0.000 & 0.2631 & 4.33 & 0.000 & 0.4090 & 7.15 & 0.000 & 0.3375 & 6.29 & 0.000 & 0.1328 & 2.11 & 0.035 & 0.1340 & 2.34 & 0.019 \\
\hline HerfIndex & 0.4326 & 1.44 & 0.149 & 0.4573 & 1.72 & 0.085 & 0.5184 & 1.86 & 0.062 & 0.7347 & 3.15 & 0.002 & -0.0301 & -0.09 & 0.925 & -0.0744 & -0.27 & 0.788 \\
\hline Suppliers & -0.0012 & -3.59 & 0.000 & -0.0013 & -3.56 & 0.000 & -0.0011 & -3.76 & 0.000 & -0.0009 & -2.87 & 0.004 & -0.0012 & -3.29 & 0.001 & -0.0007 & -1.85 & 0.065 \\
\hline Adj. R2 & & 0.4702 & & & 0.5179 & & & 0.7072 & & & 0.7490 & & & 0.5050 & & & 0.5604 & \\
\hline Industry dummies & & Yes & & & Yes & & & Yes & & & Yes & & & Yes & & & Yes & \\
\hline $\mathrm{N}$ & & 12,626 & & & 12,626 & & & 6,522 & & & 6,522 & & & 6,104 & & & 6,104 & \\
\hline
\end{tabular}

Notes: Standard errors are adjusted for heteroscedasticity and clustered on client firm. Variable definitions found in Table 2. 